\title{
مفهوم الاستغراب ودوافعه في كتابات المؤرخين المسلمين
}

أ.م.د. محمد هسيز علي السوبطي

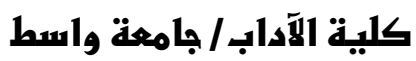

الغلاصة بالاغة العربية

نسعى في محاولتنـا البحثيـة هذه إلى تثبيت فكرة، مفادهـا: أن دراسـة المسلمين للغرب ليست وليدة العصر الحديث، بل هي أقدم من ذللك، إذ ترجع إلى العقود الأولى من تـاريخ الإسـلام، كما نسعى الى تفنيد

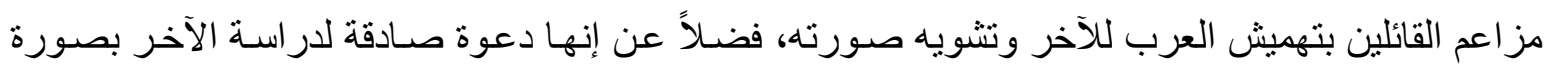
عامة و الغرب على وجـه الخصوص لنجد أنفسنا ونشخص موقعنـا منـه لان هذه الدراسـة تستلزم فهم الذات

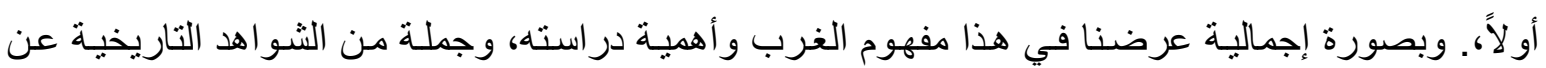

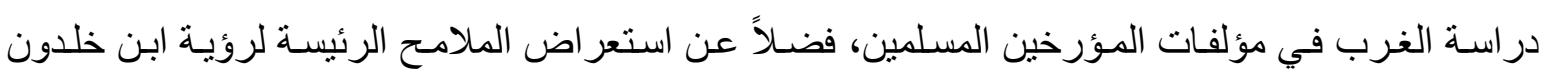
للغرب بوصفه رائداً لعلم الاجتماع. مورسه

الإقدمـة:

مما لاشك فيه ان تطور المجتمعات الإنسـنية كلاً متصل، فمهما كانت الاختلافات و الفوارق التي تميز مجتمع عن اخر أو أمة عن أخرى، فان تلك الفوارق عرضية، تتنج من نراكم مجموعة عو امل تختص

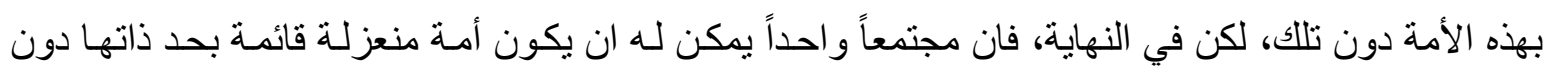

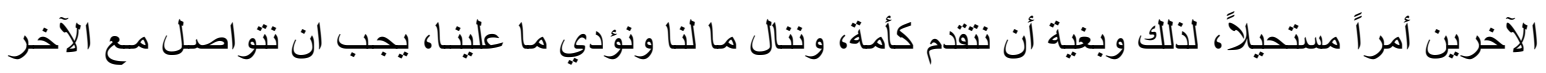

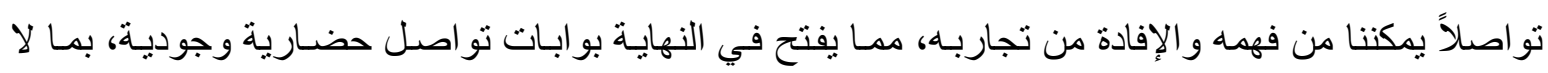
يقتصر على نقل ملامح الحضارة ومنتجاتها فحسب، بل نقل روح الحضارة ومواردها، ومن هنـا جاءت فكرة تثبيت أصالة دراسة الغرب التي تعرف اليوم بـ(الاستغراب) (Occidentalism)(')، التي سعى الكثير عرضاً أو قصداً إلى تجريمها وعدها تذللاً وخضو عاً للآخر، (الغرب)، فنبذوا كل من أقدم على دراستهم در اسة علمية وعدوه مذنباً، ولرفع اللبس في الفهم والتطبيق ارتثئنا ان نجذر لما نتمنى ان يصبح في المستقبل

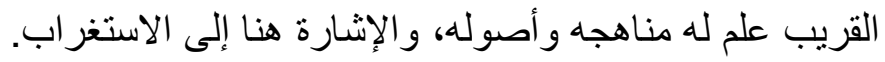
ونسـعى في محاولتتـا البحثيـة الموسـومة بــ: (مفهوم الاستغراب ودوافعـه في كتابـات المـؤرخين المسلمين) إلى تثبيت أطروحة، مفادها: أن در اسة الغرب ليست وليدة العصر الحديث، بل هي أقدم من ذلك، اذ نرجع إلى العهود المبكرة من تاريخ الاسلام، وبالنتيجة نكثف عن الحوار مع الذات الذي نحن اليوم بحاجـة

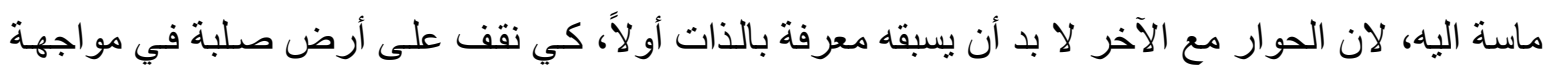
سوء الفهم و العداء اللذين هما رفيقا الجهل في أغلب الاحئ لاندان.

وبغية تتبع مقاصد البحث، وتسـيل مر اميه، صدرناه بمقدمة كثفنا فيه اسباب اختيار موضوع البحث و أهميته، وققمناه على أربعة مباحث، عرضنا فيها مفهوم الاستغر اب ودو افعه في كتابـات المؤرخين 


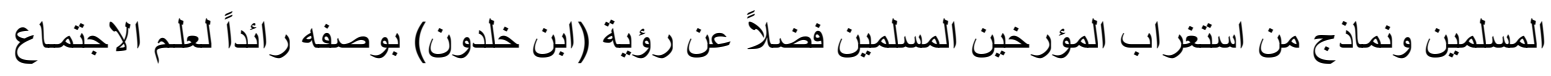

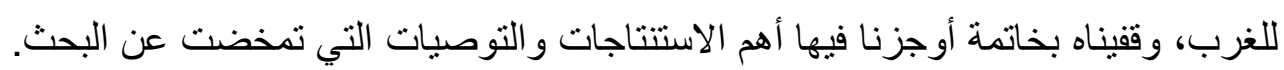

\section{المبمث الأول- هفهوم الاستغراب:}

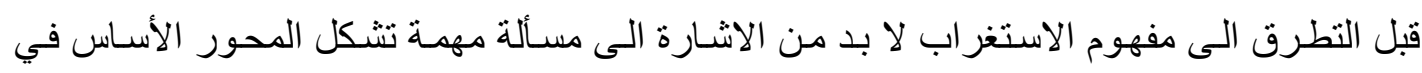

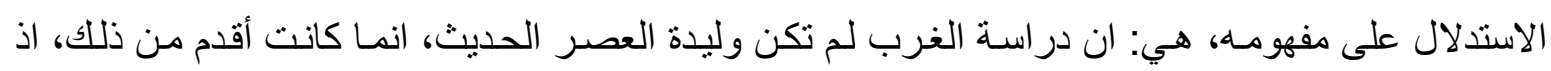

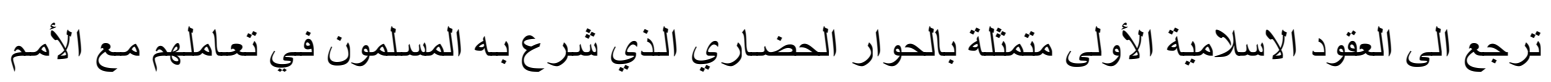

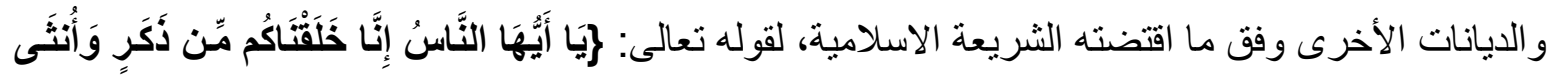

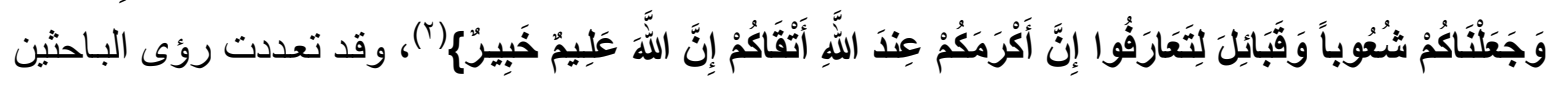

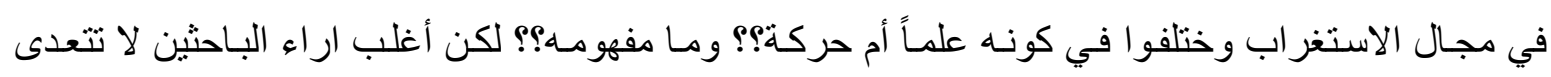

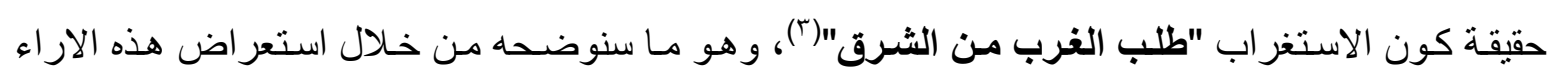
و الوقوف على المعنى الأوسع للاستغراب.

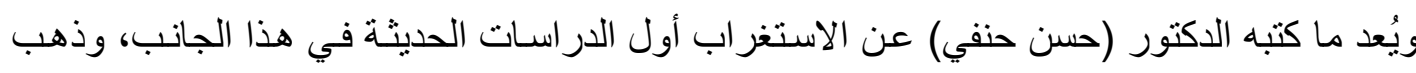

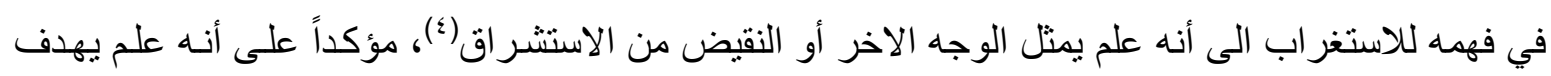

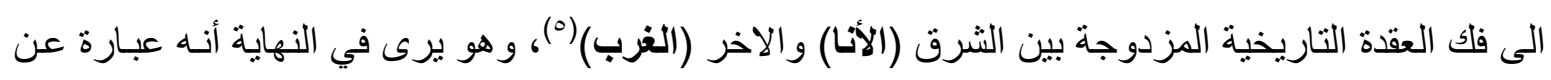

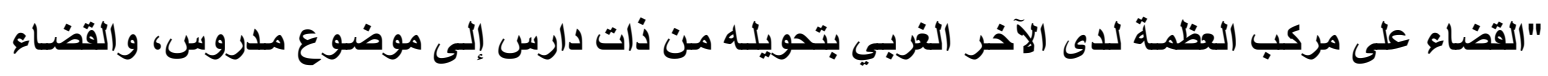

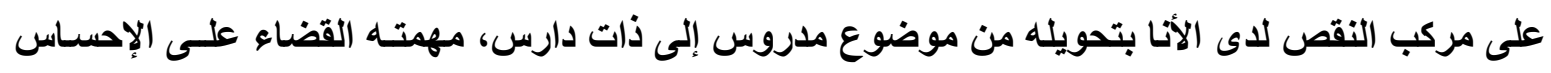

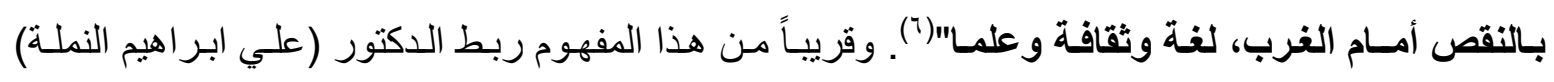

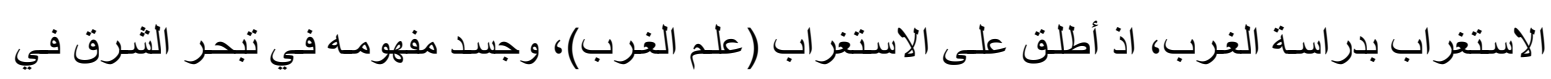

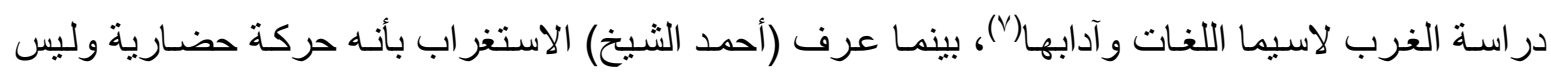

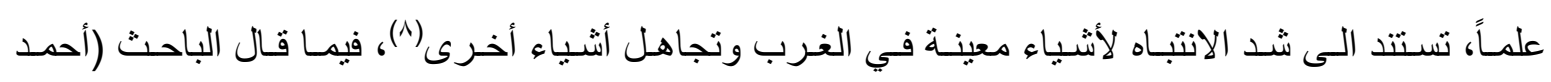

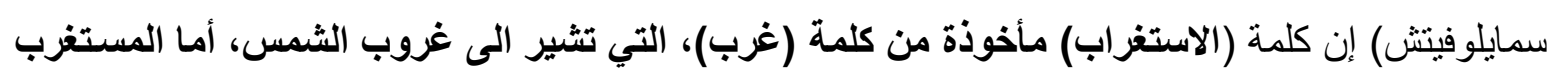

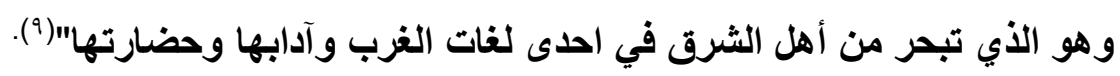

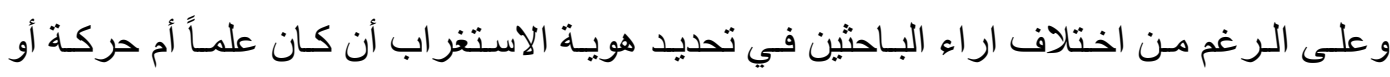

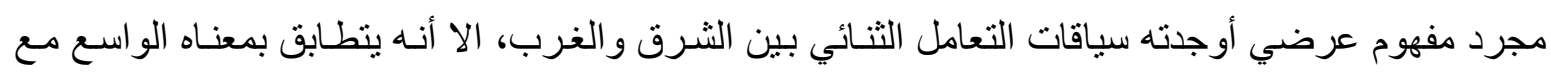

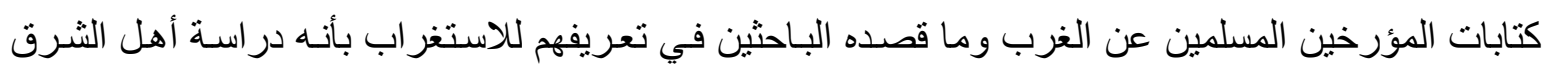

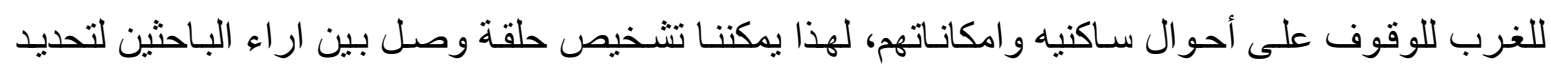

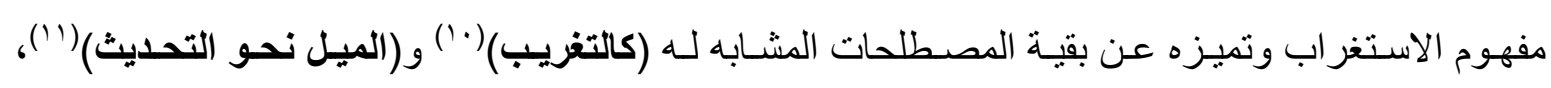

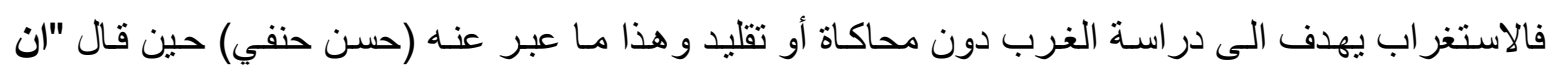

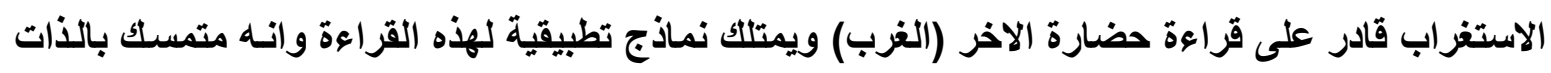

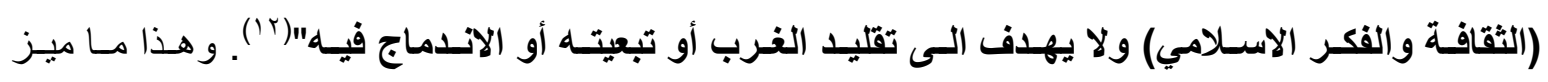

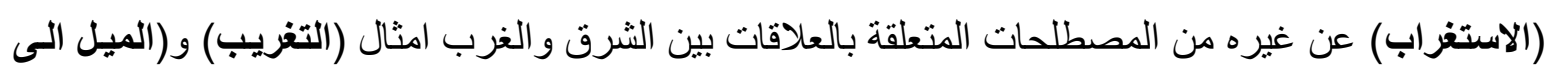


التحديث)؛ لأنها تختلف مع الاستغر اب في كون مفهوم الاخير يكمن في طلب الغرب والاطلاع على احواله بدافع المعرفة و التواصل لا التقليد و المحاكاة.

في ضوء مـا تقدم يظهر ان مفهوم الاستغراب وفق مـا كتبه المؤرخون المسلمون عن الغرب هو

حركة حضارية انطلقت وتمنلت بحب الاستطلاع والمعرفة في حضـارة الغرب، ولم تكن رداً على حركة

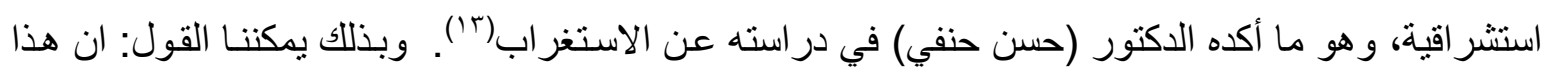

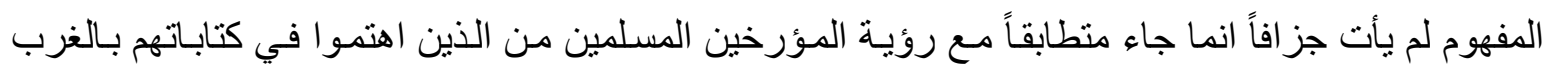
و الاطلاع على أحو اله دون الزام هذا الاهتمام او الدراسة بطبيعة مـا انتاب العلاقات بين الثرق و الغرب من صر اع سياسي واختلاف ديني، ولعل مـا ذكره (عمر بن العـاص) في وصفه للغرب بقوله: "... ان فيهم لخصال أربع، أنهم لأحلم الناس عند فتنة، وأسرعهم افاقة بعد مصيبة، وأوشكهم كرة بعد فرة، وأخير هم

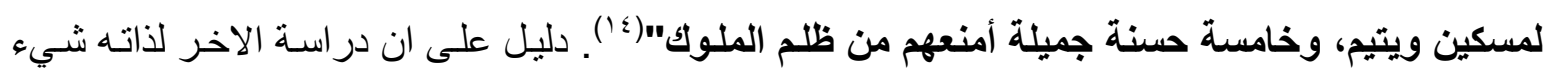
ودر استه لتقليده ومحاكاته شيء اخر. كما ان في ذللك دليل على ان الغرب كان محط اهتمـام المسلمين عامـة و المؤرخين خاصة لهذا ظهرت جذور الاستغر اب في العقود الاسلامية الأولى ـكما مر بنا_(10). وفي الو اقع لا يمكن تحديد حقبة تاريخية معينة من التاريخ الاسـلامي و عدها تمثل جذور الاستغراب

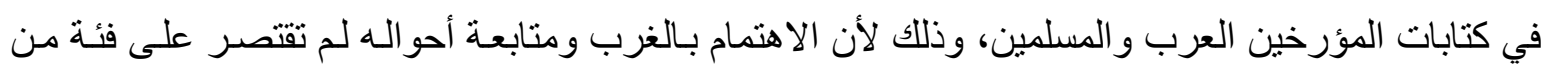
المؤرخين عاثو ا في حقبة معينة انما كان الاهتمام بالغرب مستمر اً ومتصلاً سواء في كتابات مؤرخي مختلف القرون و هذا ما سيظهر واضحاً في الشو اهد التاريخية التي سترد في متن البحث.

ومن الروايات التاريخية المتو افرة لدينا وتمثل جذور اً للاستغراب في كتابـات المؤرخين المسلمين، يمكنتا تحديد ثلاثة اتجاهات للاستدلال على جذور الاستغراب، أولها أنه يعود الى عصر الرسالة ( - (1 (هـ)

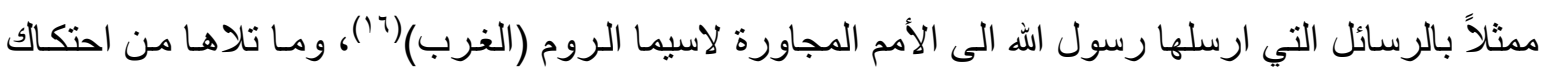

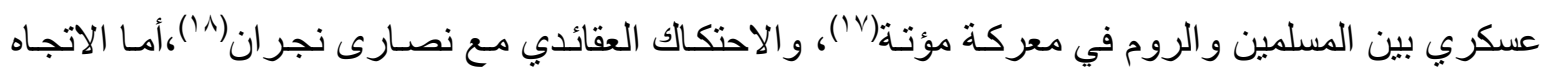
الثاني، فتمثل بظهور حركة الترجمة في أو اسط العصر الأموي وازدهاره في العصر العباسي، وما أثثر عنها من اطلاع عدد كبير من المؤرخين على المؤلفات اليونانية المترجمة من لغتها الأصلية (اليونانية و السريانية) الى العربية وأثر ذلك في زيادة معرفتهم بالغرب ودر اسة أحو الهم(19.).

فيما تمثل الاتجاه الثالث في كتابات المؤرخين المسلمين بالازدهار الفكري وتطور التدوين التاريخي

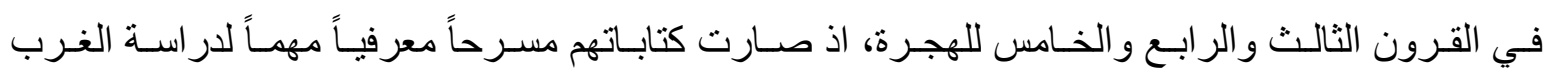
و الاطلاع على أحوالـ(·r). ولعل هذا الاتجاه هو الأقرب للاستدلال على جذور الاستغراب عند المؤرخين المسلمين.

ان أهم مـا يميز هذه الحقبة في مجال الاستغراب، أنها شـهدت ظهور عدداً من المؤرخين الكبـار تجاوزوا في كتاباتهم النطاق الجغر افي والمعرفي للغرب، و أصبح كل مـا يخصـه محل اهتمـامهم، فنشطوا في

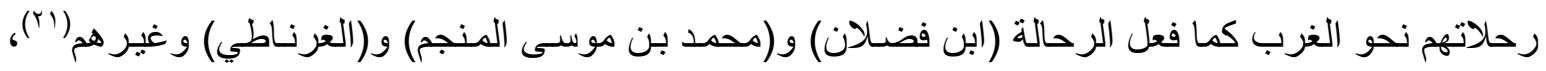


وما تركته تللك الرحلات من أثر في اماطة اللثام عن العديد من الجوانب المهمة في الغرب حتى أصبحت في متناول المسلمين بصورة عامة والمؤرخين منهم على وجه الخصوص.

كما أفرزت هذه الحقبـة عن ظهور عدد من المؤرخين كان لهم أثراً بـارزاً في الكتابـة عن الغرب سواء في الجانب الجغر افي و الاجنماعي أو الديني و السياسي، أمثال: (اليعقوبي)، و(المسعودي)، و و(ابن الفقيـه

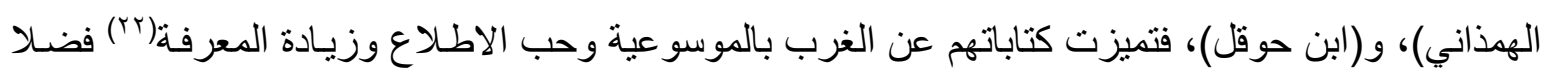
عن البحث و الرحلة و المشاهدة العينية لاستكمال الصورة المعرفية للغرب في كتاباتهم.

ومما تقدم يظهر ان مفهوم الاستغراب في كتابات المؤرخين المسلمين لم يكن ولبداً بحدث مـا أو حقبة معينة أو رداً على حركة ما انما ظهر وتبلور وارتبط مع طبيعة الثريعة الاسـلامية في تعاملها مـع الأديـان و الأمم الأخرى ومنها: (الغرب)، وهذا مـا سنوضحه في مبحثنـا القادم ضـمن در اسـة الدو افع التي تقف وراء ظهور الاستغر اب في كتابات المؤرخين المسلمين.

\section{المبشث الثاني- دوافع الاستغراب في كتابات المورخين العرب والمسلمين:}

أن ظهور الاستغراب كنمط تاريخي رافق بعض الروايـات التي أوردهـا كبار مؤرخي المسلمين لم

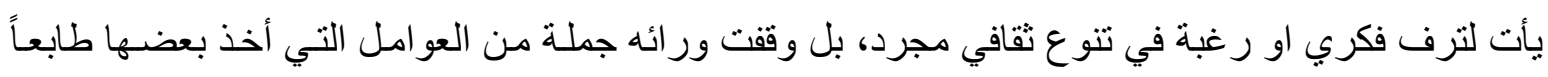

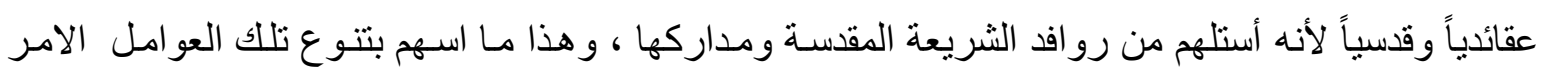
الذي فسر لنا طبيعة التنوع المعرفي الذي ميز كتاباتهم عن الغرب، إذ لم تقتصر على الجانب الجغر افي أو الديني فحسب انما كانت متنوعة لتنوع الدو افع وتعدد الأهداف من وراء ذللك.

وكان في مقدمة تلك الدو افع (الدافع الديني) المتمثل بالقران الكريم و الحديث وما ارتبط به من قضـايا أسهوت في نقل صورة عن الغرب سواء كان عند المسلمين بصورة عامـة ام عند المؤرخين منهم على وجـه الخصوص، فكما هو معروف ورد ذكر للأمم التي سبقت ظهور الاسـلام، في آيـات كثيرة، وحين تناولها القران الكريم لم تكن الغاية منها تأكيد ذكر اخبار الماضين فقط بنوع من السرد التاريخي، بل كانت الغايـة الاساس التأمل في نشاطات تللك الامم وسلوكهم و اتباع الجيد منها وتجنب السيئ لذلك لم يقصر القران الكريم ذكر تلك الامم على مجال دون اخر او على ميزة دون اخرى، فذكر لبعض الامم ابداعها العمر اني، واخرى

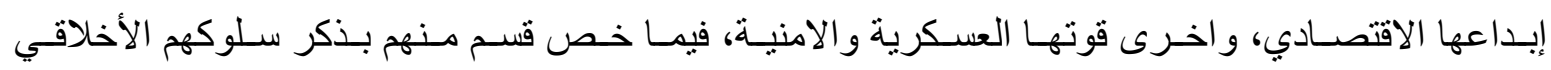

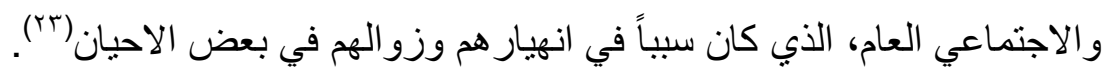

و أثر ذللك في دفع المسلمين والمؤرخين منهم للاهتمـام بهذه الأمم ومنها الغرب، ومتابعة أخبار هم

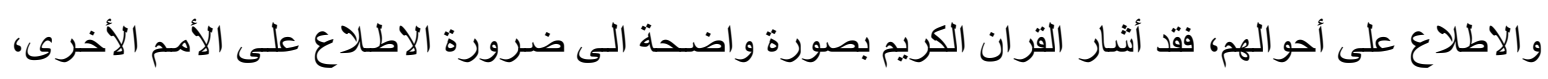

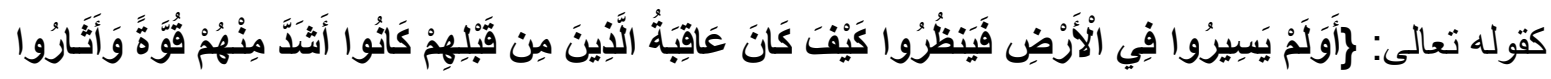

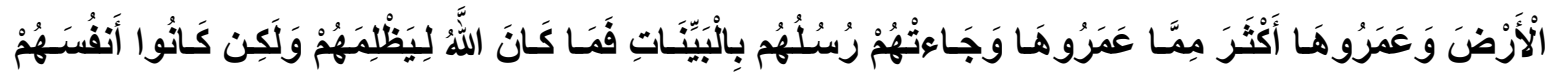

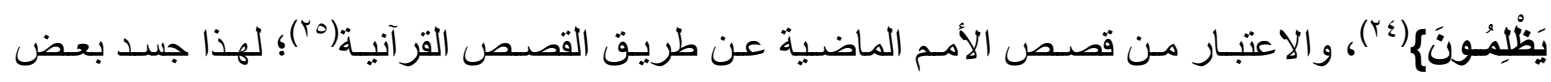
المؤرخين في كتاباتهم هذا المضمون في رواياتهم عن الغرب، فعلى سبيل المثال دفع ذكر أهل الكهف في 
القران الكريم(Tr) العديد من المؤرخين للبحث عن مكانهم والظروف التي أحاطت بهم، ممـا استوجب الأمر الاهتمام بتاريخ الروم لكونهم اضطهدوا على يد أحد ملوكهم (دقليانوس)(YY)، فضلاً عن الاستدلال عن مكانهم

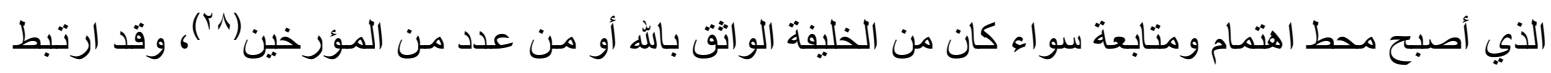
كله بالدافع الديني لورود ذكره في القران الكريم(ج"r). وفي موضـع اخـر نسـندل على أثنر هذا الدافع في ظهور الاسـتغراب لـى العديد مـن المؤرخين المسلمين من خلال ما ورد في بعض الآيات القر آنية من ذكر للسيد المسيح من حيث و لادتـه الكريمة وصلبه

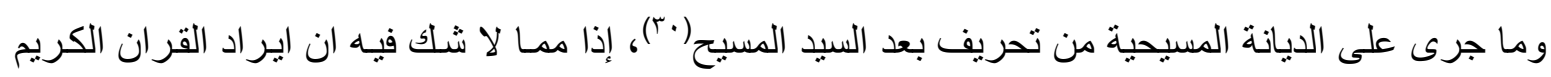

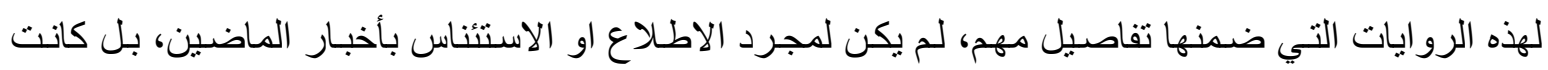
بمثابة دعوة مبطنـة لدر اسـة السلوك العـام لتلك الامم و الثخصيات وتمحيص نتاجـاتهم التي خلفو هـا وامكانيـة در استها و الافـادة منها، لذلك تسـابق المؤرخون المسلمون بنقل تلك الآيـات وتأو يلها وتجذير ها في التراث العالمي والانساني، كما فحل ذلك (اليعقوبي) الذي تطرق الى ذكر الغرب و أحو الهم من خلال حديثه عن السيد

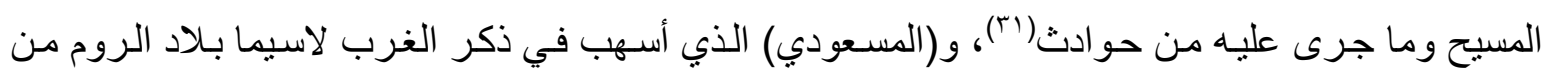
خلال السيد المسيح وما نتج عن ذلك من ظهور و انتشار للنصر انية في بلاد الغرب حظيت باهتمام ومتابعة في رواياته(rr). (r)

ولم يكن أثر الدافع الديني في ظهور الاستغر اب مقتصر اً على القران الكريم انمـا جـاء بعده الحديث النبوي الثريف واسهامه في حث المسلمين عامة والعديد من المؤرخين خاصة على معرفة الغرب و الاطلاع

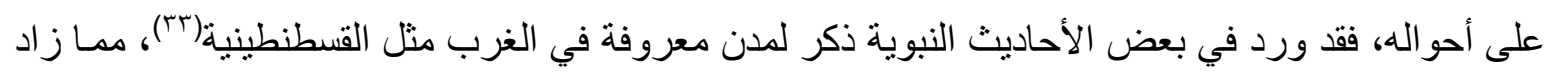
في أهمية الاطلاع على هذه المدينـة ومكانتها الدينية والسياسية لدى الروم(عَ)، و علينا ان نفهم ان الاحاديث

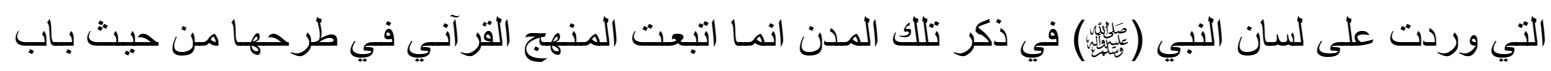
الاشارة للتدليل، لاسيما وان الحديث منهجاً واسلوباً ينحني منحى القران الكريم في الهدف ورالغاية. ومن الدو افع الأخرى التي أسههت في ظهور الاستغراب (الدافع الاجتماعي) الذي ظهر واضحاً في

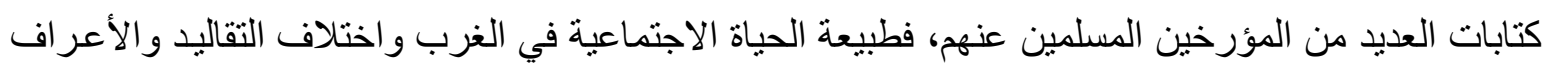

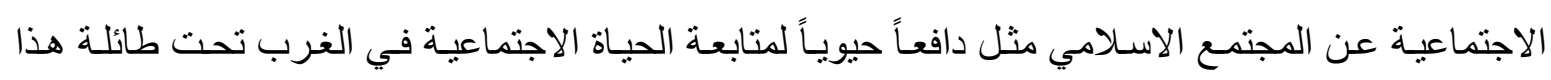

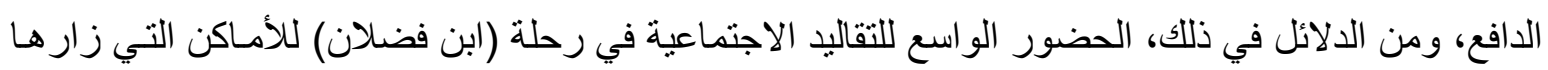

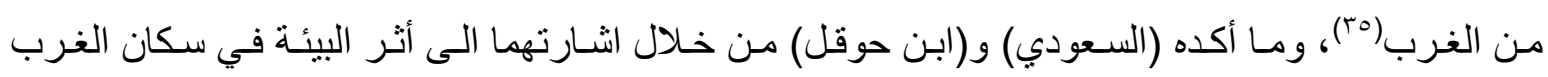
و علاقته بالحياة الاجتماعية وتكيف الانسان هناك مع هذه البيئة (بr).

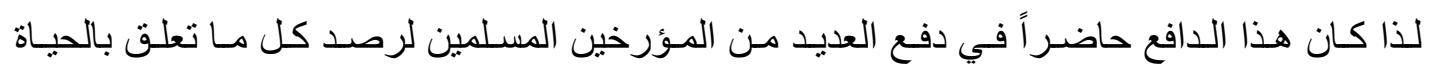

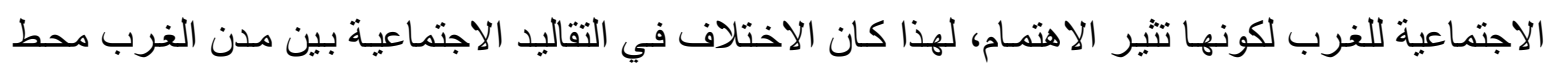

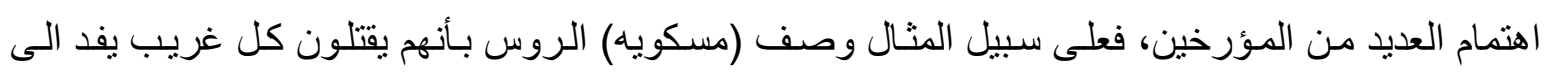

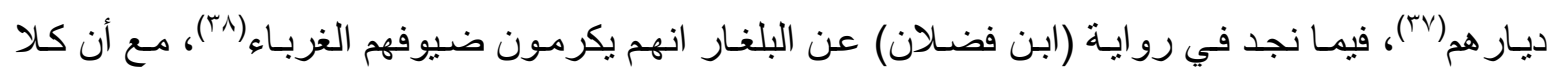
الدولتين يقعان في نطاق جغر افي واحد ومتجاورتين الى حد كبير( (rar). 
وكان للافع العلمي أثر كبير في ظهور الاستغراب في كتابات المؤرخين المسلمين، فمن الطبيعي ان

يسهم تطور وازدهار الحركة الفكرية في الدولة العربية الاسلامية في زيادة المعرفة ويشجع الرغبة في مسألة

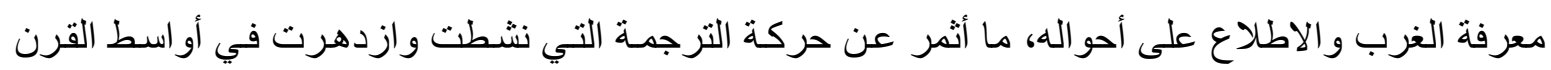

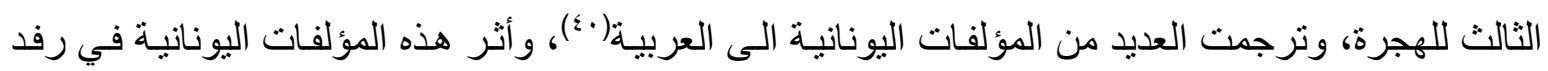
العديد من المؤرخين المسلمين بالمعلومات عن الغرب سواء كان في الجانب الجغر افي أو غيره من الجوانب، و ون الثوا اهد على ذلك محاولة (المسعودي) و(ابن النديم) على سبيل المثال لا الحصر تبيـان أهميـة هذا الدافع

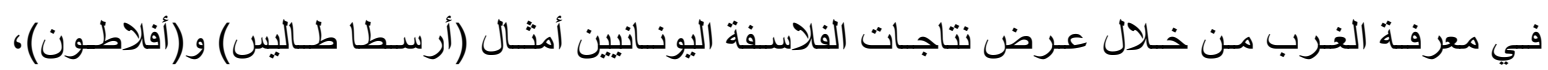
و(سقر اط) في معرض حديثهم عن الأوضاع السياسية في الغرب وخاصة في عهد الاسكندر المقدوني (جسب-

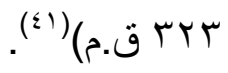

أما العلاقات السياسية بين الثرق و الغرب سواء كانت في مجالها الدبلوماسي أو غيره فقد شكلت

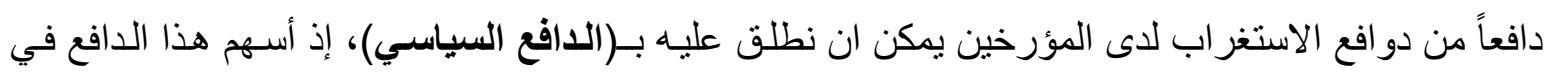
نقل أمور عن الغرب مكنت العديد من المؤرخين من الاستفادة منها في زيادة معلومات عن جوانب في الغرب مرتبطة بهذا الدافع ، فعلى سبيل المثال بناءً على طلب ملك البلغـار أرسل الخليفة العباسي المقتدر بـاله (ابن

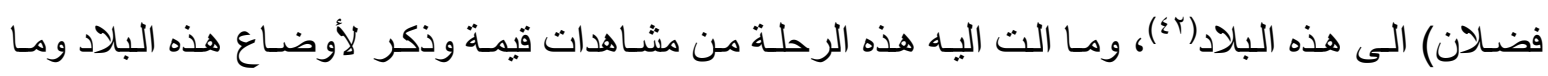

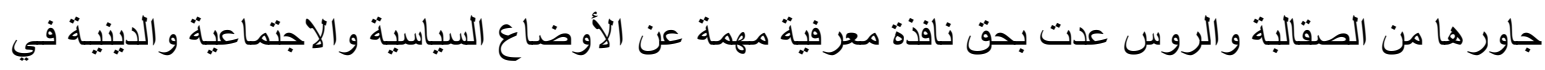
هذه الأقسام المهمة من الغرب(rاء)، لذا اعتمد (ياقوت الحموي) كلياً على هذه الرحلة في وصف وتثبع الكثير

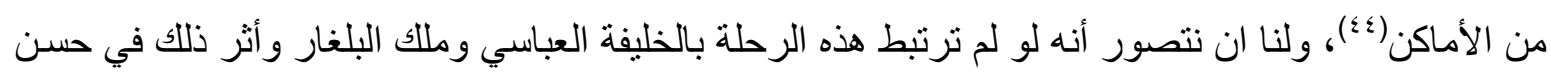
استقبال صاحب الرحلة وتسهيل مهمته و السماح له في متابعة أوضاع هذه البلاد تحت رعاية ملكهم الذي سمح

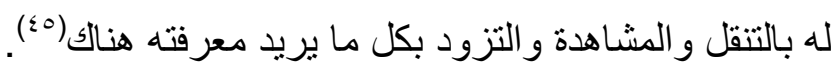

وليس بعيداً عن ذلك، نتلمس صسورة أخرى من صور هذا الدافع متمثلة بالأسرى المسلمين لدى

الروم، اذ أسهم قسم من هؤلاء الأسرى في نقل صورة عن الغرب بوصفهم شهود عيان في نقل الأخبار حين بـ هين

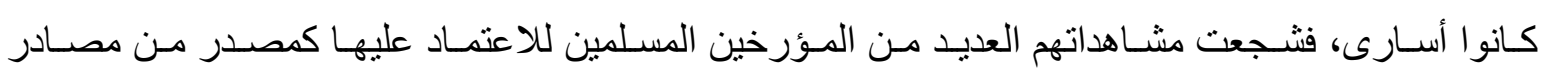
معلومـاتهم عن الغرب، لذا اعتمد كل من (المسعودي) و(الاصطخري) على مـا ذكره (مسلم بن أبي سلم

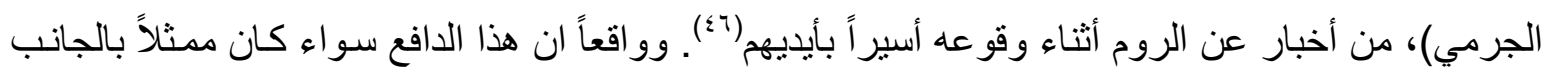

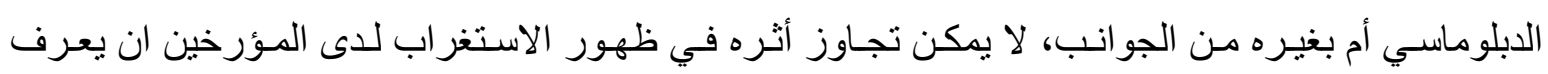

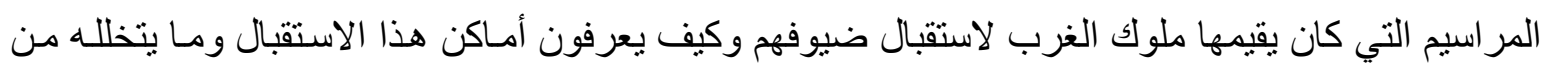
ممارسات دبلوماسية تثير أذهان المؤرخين للانتباه عليها ومعرفة هذا الجانب من الغرب.

وفي طور البحث والاستدلال على دو افع الاستغراب في كتابـات المؤرخين المسلمين لا يخفى أهميـة

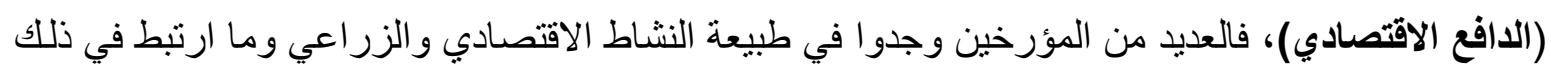

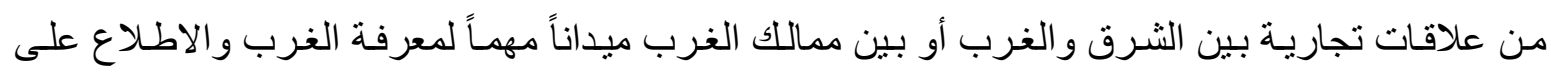
أحو اله من خلال هذا الدافع، ففي مجال النشاط الزر اعي في الغرب وضع العديد من المؤرخين المسلمين هذا 
النشاط نصب أعينهم ومتابعاتهم للغرب، فاثتتهار البلغار و الصقالبة بزراعة الحبوب (الحنطة والثعير) دفع

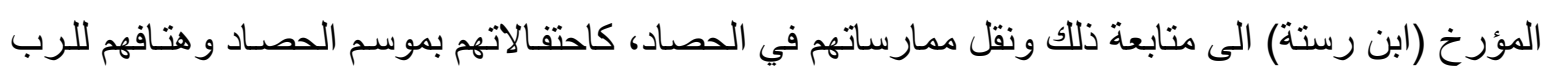

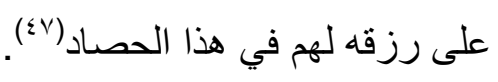

\section{المبمث الثالث- نماذج من استغراب المؤرخين المسلمين:}

1- البجانب العسكريs:

يبدو أن طبيعة المرحلة العسكرية التي عاثتتها الدولـة العربيـة الاسـلامية منذ نشـأتها حتى سقوطها، دفعت بالمؤرخين الى تولية الجانب العسكري ودر استه عن أمم الغرب أهمية خاصـة، فمن دون شك هو اكثر لهر

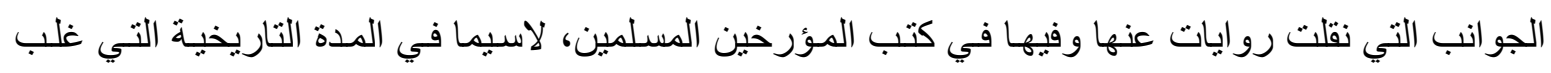

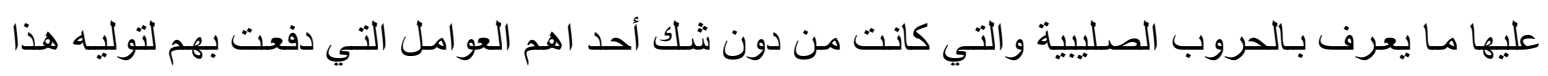

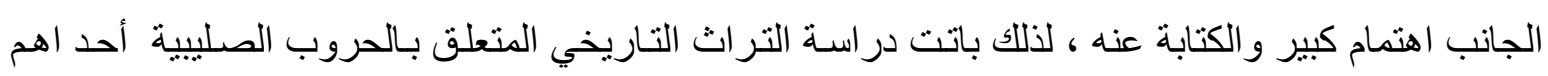
الطرق و الوسـائل التي يمكن لنـا أن نستدل من خلالها على العديد من نمـاذج استغراب المؤرخين المسلمين سو اء اكان في مجـال الأسـاليب العسكرية للفرنج أم التدابير والأسلحة وغير هـا من المسـائل العسكرية، فهذه فئه

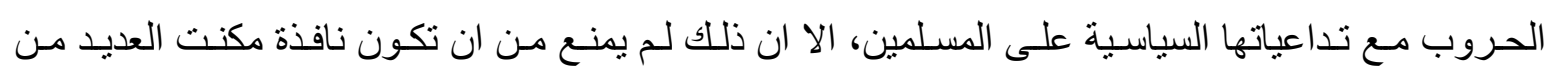
المؤرخين من الاطلاع على طبيعة النظام العسكري للإفرنج من باب المعرفة والاطلاع.

وعلى الرغم ممـا شـعر بـه أغلب المؤرخون المسلمون من بغض وحقد تجـاه الغرب، الا انهم في مواطن عدة لـ ينكروا لهم تقدمهم الحربي ونجاحـاتهم وخصـالهم العسكرية، فعبر كثير منهم عن اعجابهم بأساليبهم العسكرية وخططهم، وربما كان لذكرها هند بعضهم دعوة من بعيد للإفادة منها، ولم يكتفوا عند هذا

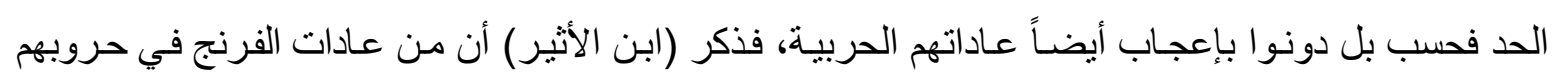

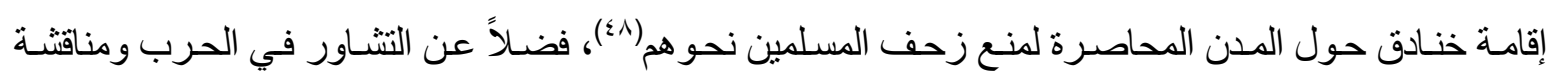

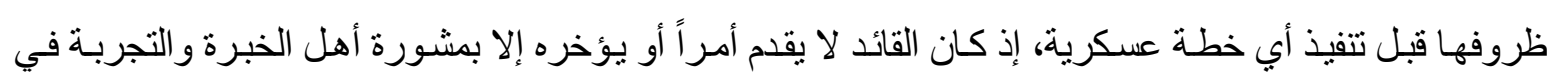

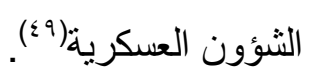

وفي المجال العسكري أيضاً درس المؤرخون المسلمون صناعة الأبر اج الحربية التي برع الصليبيون في صناعتها، وذكروا أحجامها من ناحية الطول و العرض و العلو، فحدد (ابن القلانسي) طول إحدى الأبر اج بأربعين ذر اعاً، بينما بلغ آخر خمسين، في حين بلغ طول برج مـا يوازي سور مدينـة معرة النعمان(.0)، وقدم (ابن الأثير)

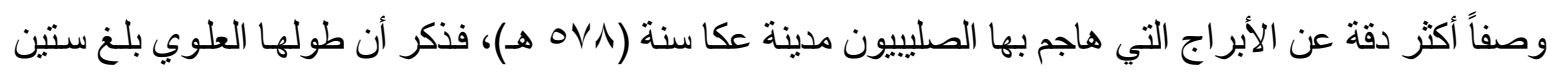

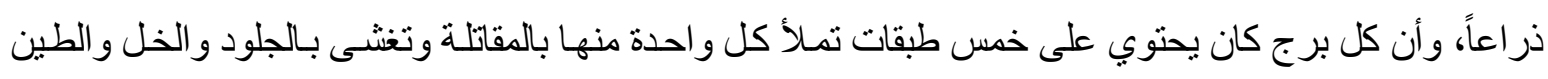
و الأدويـة التي تمنع النـار من إحر اقهام(10)، ولم يكن هذا التفوق في مجال صناعة الأسلحة سـوى انعكاس أمين لمجتمع حربـي شـكلت الحروب مصـادره الأساسية، كمـا لفت انتبـاههم نظـام الفروسية الذي كـان عمـاد الحيـاة الأوروبية في العصور الوسطى، فنتاولو ها بالبحث والدراسة ووثقوا أخباراً هامة عنها، دل على ذلك مـا ذكره (ابن

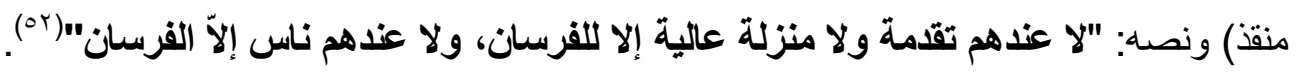


وتطرقوا كذللك في الجانب العسكري الى دور المرأة في هذا المجال، فذكر (ابن الأثير) في سياق

الأحداث التي أعقبت سقوط القدس بيد المسلمين أن الصليييين حشدوا الحشود وجنّدوا أنفسـهم، وكان من ضمنهم

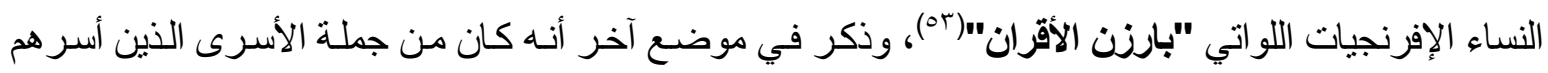

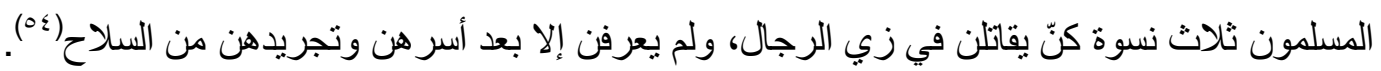

وخصص (الأصفهاني) حيزًا مهماً من كتاباته عن النساء الإفرنجيات و أكد أنهن كان يقتدين بالفرسـان، فلا

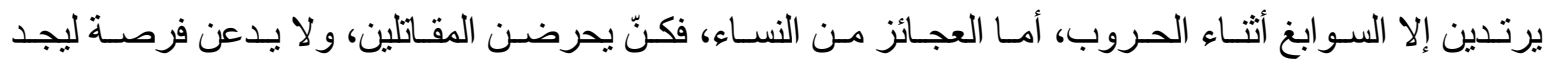
الاستسلام مكاناً في نفوسهم، بل كنّ يعتبرن المشاركة في القتال عبادة، وهو ما عبّر عنه بقوله: "وفي الفرنج نسـاء فوارس، لهن دروع وقوانس ويبرزن في حومـة القتـال، وكل هذا يعتقلنه عبـادة"(00)، ولعل جل هذه هذه القرائن

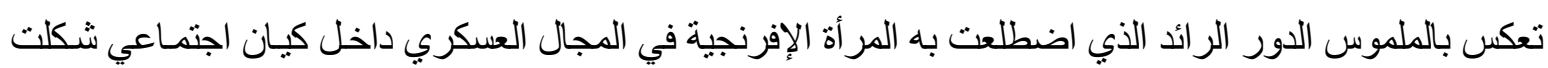
الحرب حجر الزاوية فيه.

\section{r- الجانب الاجتما عي:}

مثلت الحياة الاجتماعية في الغرب ميداناً خصباً للعديد من المؤرخين المسلمين من الذين أظهروا في كتاباتهم عن الغرب اهتماماً كبيراً في هذا الجانب، وقدموا نمـاذج بينوا من خلالها مدى اعجابهم ومتابعتهم لهذا مناء الجانب من الغرب.

ففي مجال ملابس الغرب، وصف (ابن رسته) ملابس الصقالبة بأنها كانت ذات أردن ضيقة، ومن

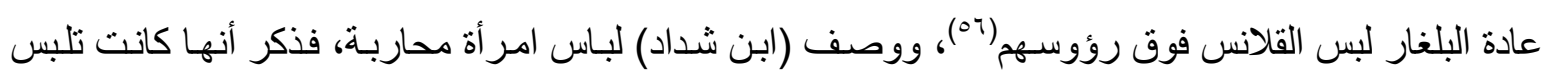

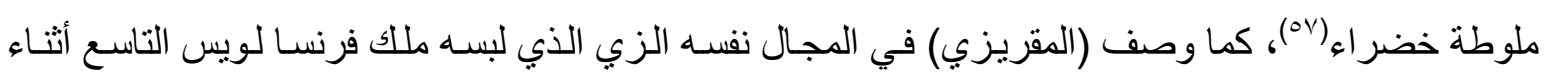

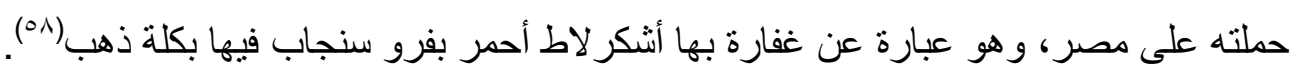
ونوه (ابن الأثير) بالصدد نفسـه الى مـا دل على ان الافرنج الصليبين يرتدون السواد في المـآتم(ه9،

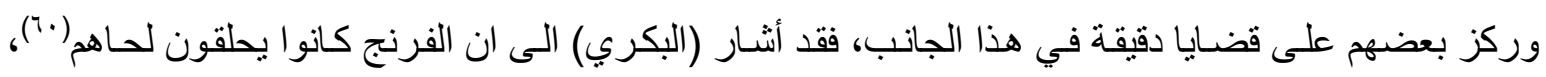
و أكد (ابن شداد) ذلك بإنشارته الى ان المسلمين كانو ايحلقون لحاهم في بعض الحملات العسكرية ضد الصليبيين لتمويهـم حتى يظهروا كالإفرنج تماماً) (1). وبحسب كتابات المؤرخين المسلمين نستشف أيضاً في مجال ملابس الغرب أنسه لم تكـن من عـادة

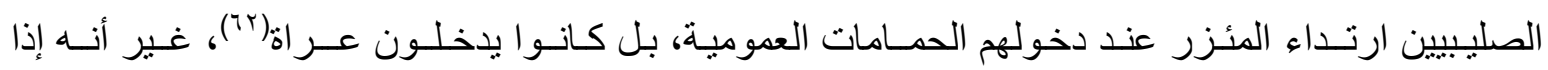

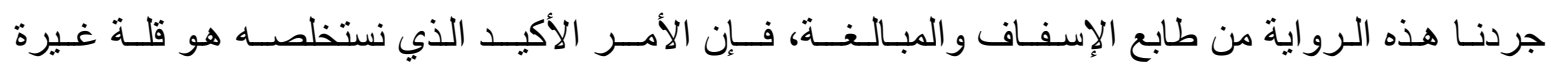

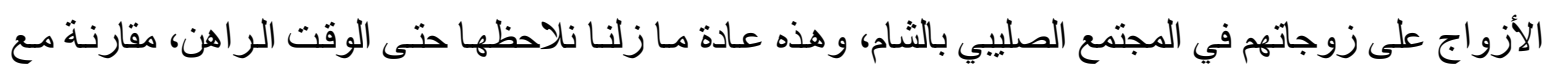
المجتمع العربي ذي الطابع الرجولي الذي تتكل فيه الغيرة على النسـاء أحد المكونـات الأساسية للثخصبة العربية الإسلامية.

ولم يقتصر اهتمام المؤرخين المسلمين في هذا الجانب على الألبسـة في بـلاد الغرب، انمـا شملت الأطعمة و الأثاث، وقاموا معلومات ـعلى قلتها- كانت في غايـة الأهمية، ومن ذللك مـا ذكره (ابن منقذ) في روايـة أسندها 
إلى أحد أصدقائه ذكر فيها عنه أنه جلس إلى مائدة إفرنجي و عليها طعام "في غايـة النظافة والجودة"(זّ). وهي عبارة يفهم منها اهتمام فئة من الإفرنجة على الأقل بأمور التخذية ومـا تستلزم من أمور صحية كالنظافة والعناية بالجودة، لكنتا نميل إلى الاعتقاد بأن هذا الوصف لا بشمل المجتمع الصليبي برمته، ويحتمل أن يشكل استثناء،

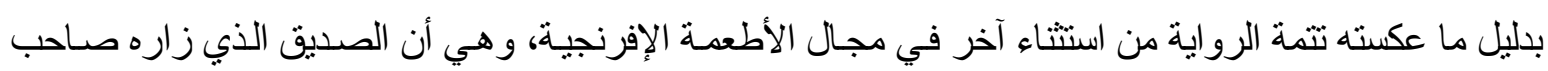

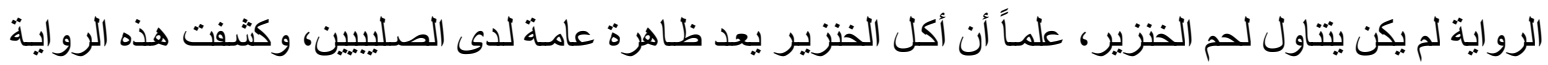
ضوءً آخر اً على تتغيل الإفرنج لطباخات مصريات، إذ أن الثخص الذي أنتـار إليه النص كان لا يشغل إلا هذا

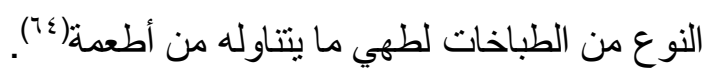

وبين (ابن الأثير) أنواع الأثاث الذي استعمله الصليبيون داخل بيوتهم في مدينة القدس، فإبان خروجهم

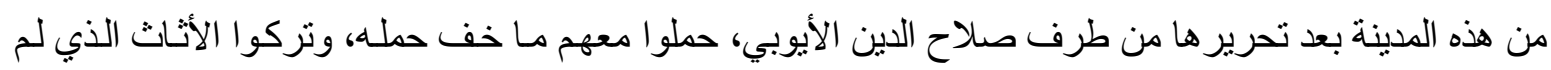

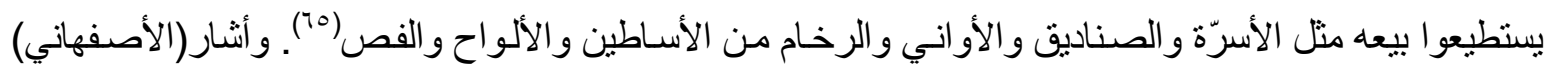

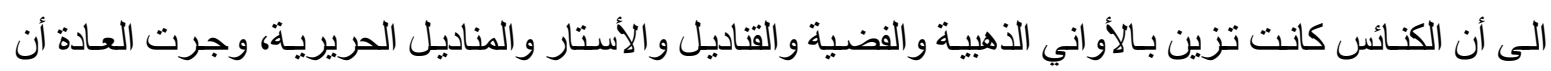

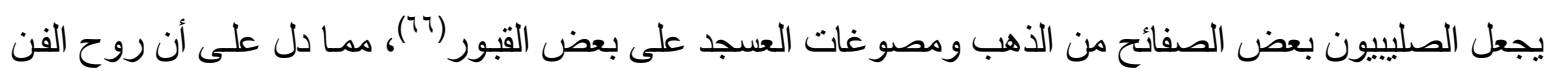
و التجميل كانت شائعة لدى المجتمع الإفرنجي.

وشــلت اهتمامـات المـؤرخين المسـلمين فـي مجـال الحيـاة الاجتماعيـة للغـرب، (اللغـة المتداولـة بـين الصليبيين) بالثام، لكن نصييها كان أقل من المجالات الباقية، وبروايات غير مباثرة، مثل رواية (ابن منقذ) التي أنشار بها الى أن امرأة إفرنجية لقيته في السوق، فصرخت في وجهه "وهي تبربر بلسـهـه" دون أن يستطيع فهم

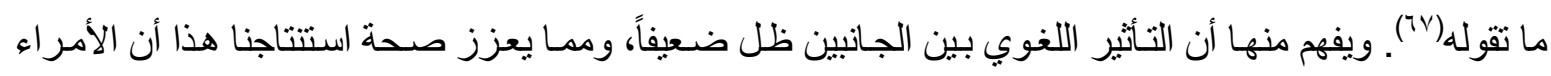
المسلمين أنفسهم اضطروا دائماً إلى استقدام مترجمين لاستيعاب اللغة الإفرنجية التي ينطقها المبعوثون أو الأمراء الإفرنج أنفسهم، بل حتى الأسرى('ال).

وشملت اهتماماتهم أيضاً (المرأة الإفرنجية)، فوثقوا أخبار اً متتوعة عنها في كتبهم، لكن مـايؤخذ عليهم عدم تخصيص مو اضيع مستقلة عنها، بل جاءت صورتها ضمن السياق العام للأحداث، وقد يفسر ذلك بقلة عدد النساء الإفرنجيات اللائي أقمن في بـلاد الثـام بسبب أن معظم الذين قصدو ها كانوا من فئَة الرجال المقاتلين كمـا ذهب إلى ذلك أحد الباحثين(79). لكن من غير المستبعد أن يكون عددهم قد ارتفع مع مرور الزمن، ومهما كان

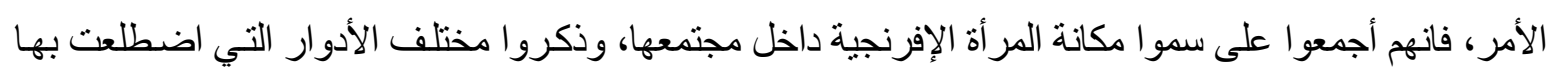
في الحياة السياسية والعسكرية، وأول مـا لفت انتبـاههم الحريـة التي تنعم بها المر أة الإفرنجيـة، لاسيما في مجال الحياة الجنسية، إذا صدقنا روايـة طريفة أوردهـا المؤرخ (ابن منقذ) أنه لم يكن غريباً أن تلتقي المر أة الإفرنجية برجل آخر وتتفرد به للتحدث معه وزوجها ينتظر ها؛ و إذا ما أطلات في الحديث، تركها مع (صديقها) ومضى إلى إنى

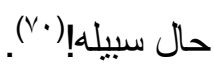

ولا ندري في أي مسـتوى مـن درجـات المصداقية يمكن أن توضـع مثنل هذه الروايـات حـول الإباحيـة الجسدية، علماً أن (ابن منقذ) رواها من موقع المشاهد اللصيق بالحدث، لكن يبدو مع ذللك أنها لم تسلم من أغلال

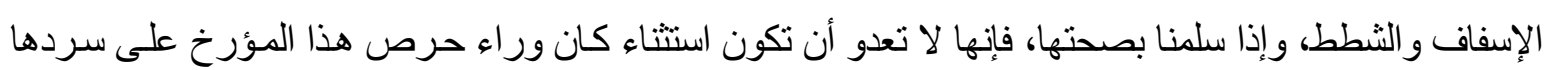


لإثارة القارئ وتتـويقه، بيد أن مـا يستتنجه الباحث من هذه الروايـة بعيداً عن عنصـر الغرابـة فيها، يتجلى في الاختلاط الذي كما يقع بين المسلمين والصليبيين، مما يدحض فكرة انعدام التعايش بين الجانبين. وأما صورة المر أة الفرنجية فقد وصفتها الكتابات التاريخية الإسلامية بأنها كانت متحررة إلى حد الميوعة،

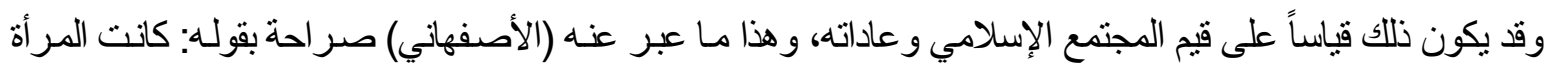

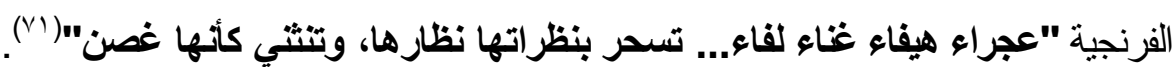

و على الرغم من هذه الأوصـاف وغيرهـا، التي تحط من قيمـة المرأة الإفرنجية على مستوى المرجعية

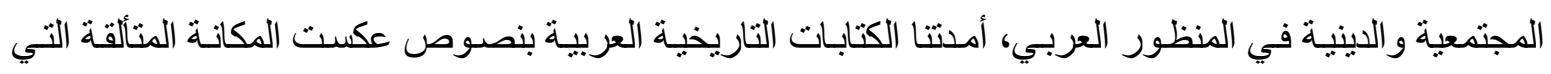
بلغتها بعض النساء الإفرنجيات داخل المجتمع الصليبي بالثنام، ونسوق في هذا الصدد أخبار ملكة وصفت بأنها

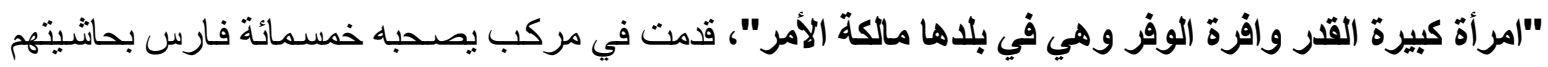

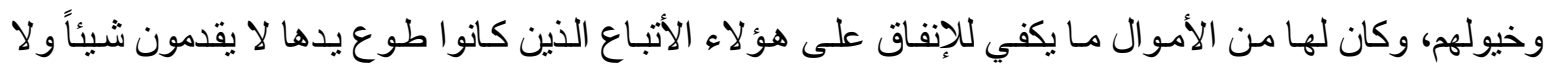

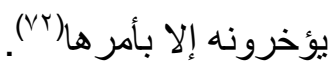

بيد أنـه على الرغم من هذه الحريـة التي تمنعت بها المر أة الإفرنجية والمكانـة المتألقة التي حازتها في هرمية المجتمع، فإن حريـة زواجها لم تكن بيدها، وهو مـا نستشفه من روايـة رغبة تزويج الملك ريتشـارد قلب

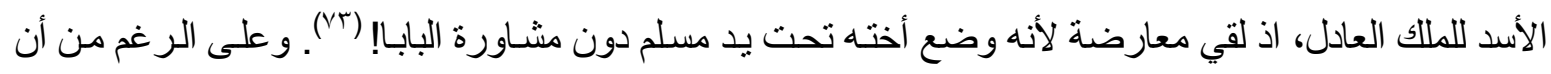

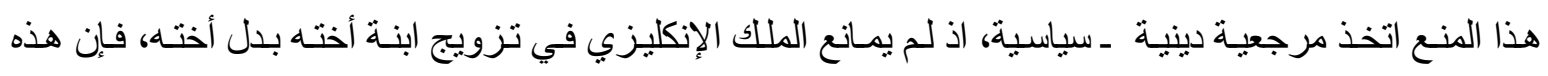
السلوكيات عكست مدى إمكان تطبيق منل هذه القرارات على المر أة دون الرجل، وتعويض امر أة بـأخرى وكأنها مجرد سلعة تستبدل حسب رغبة الرجل أو ذوي النفوذ الديني وأصحاب القرارات، و على العموم، فالقاعدة السـائدة لدى الإفرنج أن المرأة الثثب تتزوج بإذن البابا، بينما المرأة البكر يزوجها أهلها، وفي كلتا الحالتين، لا نلمس موقعاً لحرية الزواج لدى المرأة الإفرنجية. وفي رواية تانية ذكرها (الأصفهاني) أن ريتشـارد قلب الأسد ولى ابن أخته الكونت هنري مدينة صسور بدل المركيس الذي ترك زوجته، فتزوجها هنري وهي حامل، مما أنثار استغر اب المؤرخ العربي الذي تسـاءل

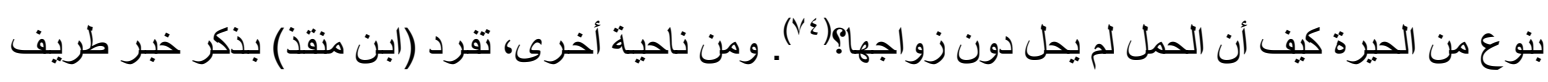
يهم فضاء النساء الإفرنجيات وإيجايياتهم، وهو أن امر أة عجوزاً ساهمت على الرغم من كبر سنها في سباق نظمـهـ

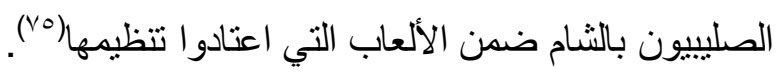

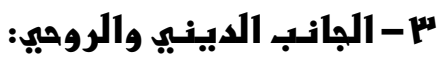

لم يغفل المؤرخون المسلمون توثيق أخبار (النواحي الاينية والروحية) للغرب، فقد أفصحوا عن أهمية

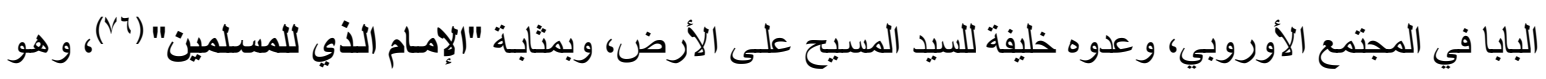

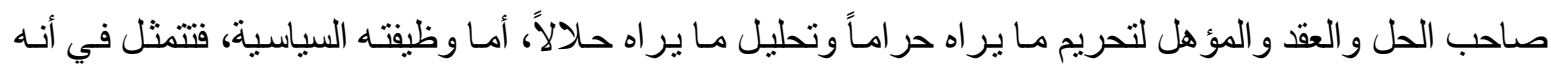

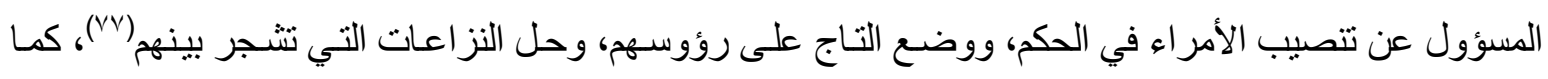

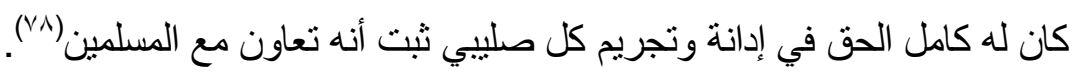


على أن ذلك لم يكن قاعدة مطلقة، بل هنالك استنثاءات كثفتها نصوص عربية أخرى ثمثلت بعدم راحة بعض الأمر اء الصليبين للبابا وسلطته الدينية، على اعتبار أنه من غير المنطقي أن يكون البابا، وهو على رأس قمة السلطة الدينية، دون نسب و لا قرابـة مع السيد المسيح، وقد أخذت هذه الاتنقادات وجاهتها من خـلال مقارنـة اعنة بعض أمر اء الإفرنج بين البابـا الذي لا يستتد إلى أي أصل أو نسب ديني، وبين الخلفاء المسلمين الذين ارتبط معظمه بصلة قرابة مع النبي محمد (عليه الصـلاة والسـلام)، بيد أن هذه الانتقادات كانت تجلب عليهم نقمـة البابـا و غضبه، فكان بعضهم أحياناً يتعرضون للقتل ثمناً لتجرئهم عليه( (va).

و على الرغم من سوداوية هذه الصورة من الناحية الرسمية، فـإن المؤرخين المسلمين تتـاولوا بعض الجوانب المضيئة في الحياة الدينية داخل المجتمع الصليبي بالثام، فكثنفوا عن حياة الزهد و العبادة التي لم تتعدم في

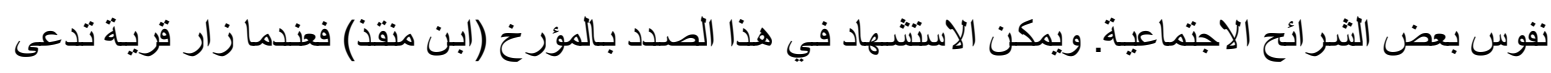

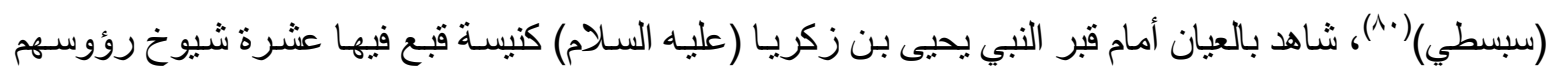

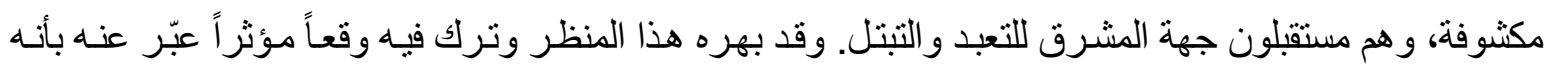
"يرق له القلب"('^)، و هو نص عكس حياة الزهد التي سادت المجتمع الصليبي خلال العصر الوسبط، كما أنتارت نصوص أخرى إلى اعتناق بعض الصليييين الليانة الإسلامية، ومنها ما ذكره (ابن منقذ) بأنه كان في جملة أسرى إحدى الحملات العسكرية امر أة إفرنجية عجوز ومعها ابنة شابة حسنة الخلق لها ابن اعتقى الإسلام(rائ.

ع-1الجانب القضائي:

من المجالات الأخرى التي ركز على دراستها المؤرخين المسلمين في الغرب، (النظام القضسائي)، وكانت لهم رؤية ايجابية بصدده، عبر عنها (ابن منقذ) بقوله: أنهم "أصحاب الرأي وأصحاب القضساء والحكم" (ז^^)، ووصف جهاز هم القضائي بالنز اهة والاستقلال التام عن السلطة التنفيذية، لأنه اذا صدر حكم لا يستطيع

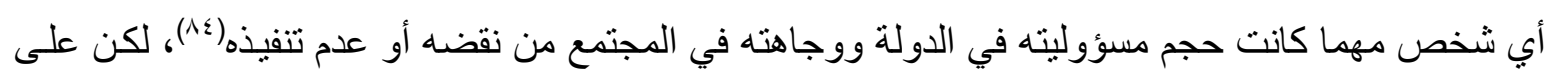
الرغم من هذه الرؤية الايجابية للنظام القضائي عند الاخر، الا أنه لم نجد من المؤرخين من دعا الى تطبيقه

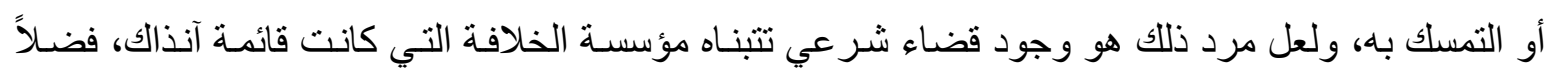
عن عدم مقبولية الاقتباس من الغرب.

0

شملت اهتماماتهم (التطور العلمي لاى الإفرنجة)، إذ قدموا في هذا الصدد مـا عكس نبوغهم الفكري، وقد

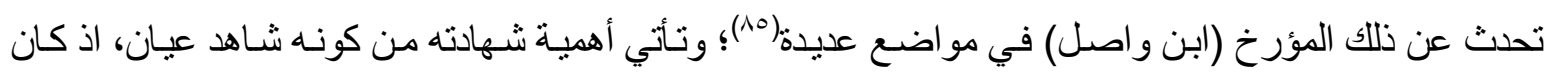

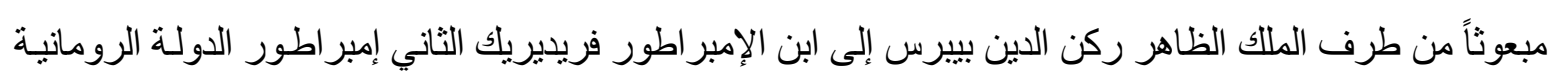

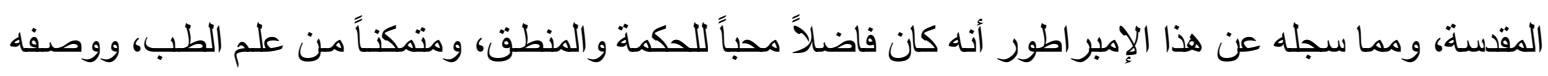
في موضـع آخر بأنـه شـوف بـالعلوم العقلية؛ و لا غرو، فقد كان "يحفظ عثر مقالات من كتاب أوقليديس في هي

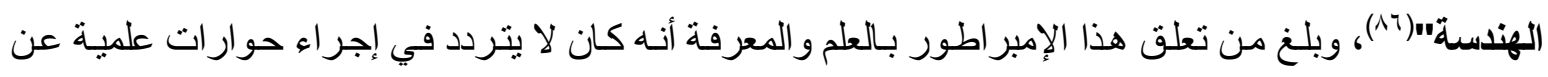
طريق المر اسـلات؛ وحسبنا أنه بعث إلى الملك الكامل مسـائل حكمية وهندية ورياضية معقدة ليختبر بها قدرة العلماء المسلمين الموجودين في بلاطه، فنجح هؤلاء في حلّ كل المسائل التي طرحها على أنظار هم(هץ. 


\section{1-1الجانب 1الاقتصادي:}

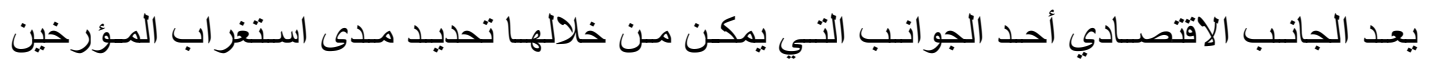
و اهتمـامهم بـالغرب، فقد كانت طبيعـة الحيـاة الاقتصـادية في الغرب سواء كانت ممثلـة بشكلها الزراعي او التجاري محط رد ومتابعة من المؤرخين المسلمين.

ففي رواية (ابن رسته) بين ان ما تشتهر به بلاد البلغار من زر اعة الحبوب لقوله: "... هم قوم لهم

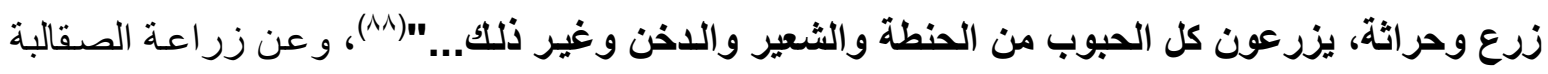

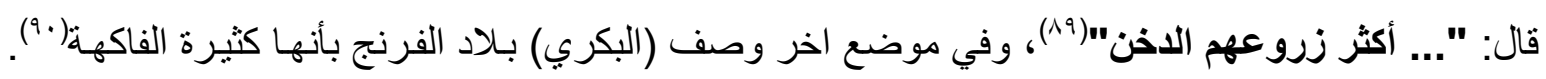

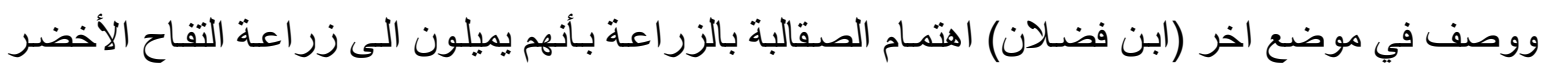

ويعدونه من النباتات المفضلة لديهم لاسيما اذا كان شديد الحموضة، واشتهروا كذلك بزر اعة البندق( (9). ومثلت التجارة بوصفها جزءاً من الحياة الاقتصادية للغرب احدى صور اهتمـام المؤرخين المسلمين بالغرب، وذكر (المسعودي) في هذا الصدد أن بلاد البرطاس اشتهرت بتصدير جلود الثعالب السود، و اقتصر

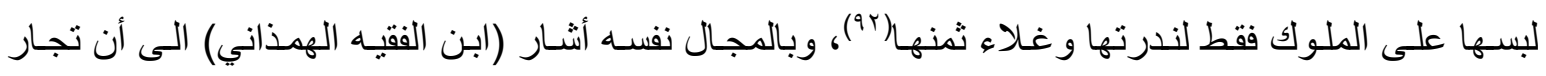

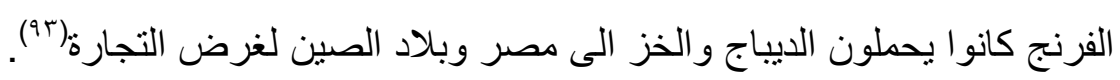

\section{المبمث الرابع- ابن خلدون والاستغراب:}

في القرن التاسع الهجري أخذت دراسة الاخر ت تتحول الى دراسـة عملية أكثر منها دراسـة اخباريـة

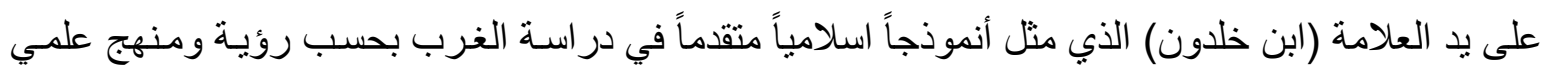

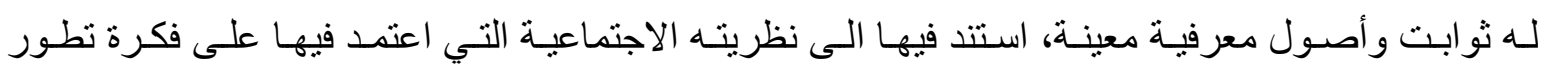

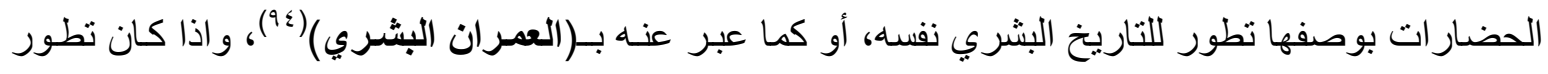

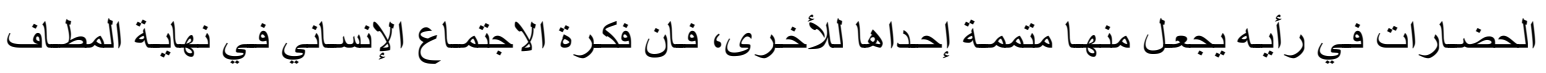
ضرورة لا يمكن الاستغناء عنها، حتى ذهب إلى حد التحذير من ضرورة السهو والغفلة عن ذلك، فقال: "من الغلط الخفيّ في التاريخ الذهول عن تبدّل الأحوال في الأمم و الأجيال... لا يتفظّن لـه إلاً الآحاد من أهل الهل

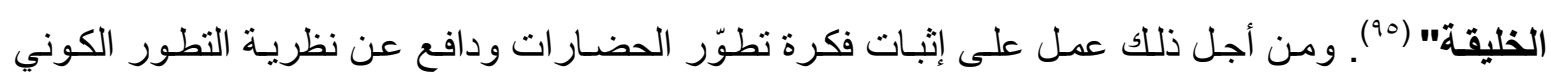
الكامل بناءً على نر اكم تجارب المجتمعات المختلفة.

ولعل من أروع ما اكد عليه (ابن خلدون) أن التراث التقافي للأمم السـالفة لا يزول بزو الها أو يقف

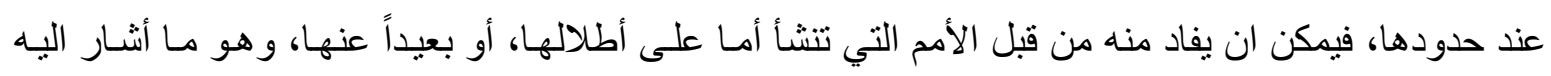

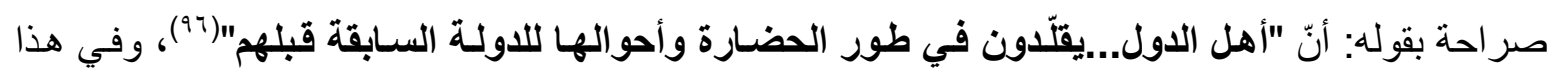
الإطار أقرّ بإفادة العرب من الموروث الحضاري الفارسي والبيزنطي، بل أنهم أبدعو ا في تطويره حتّى أنهم

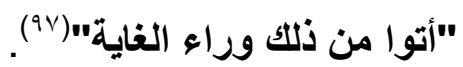

و عليه فـان (ابن خلدون) لم ينظر إلى (الآخر) من المنطلق الذي انطلق منـه أقرانه، بـل وجد فيه

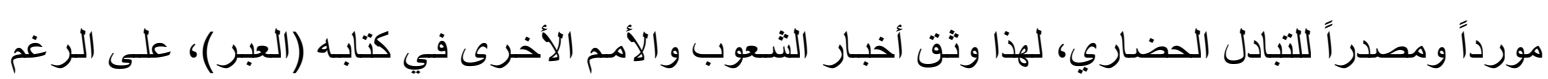


من انه خصصده لتاريخ العرب و البربر في بلاد المغرب، وفي ذلك دليل قوي على التوجهـ الإسـلامي لدراسـة

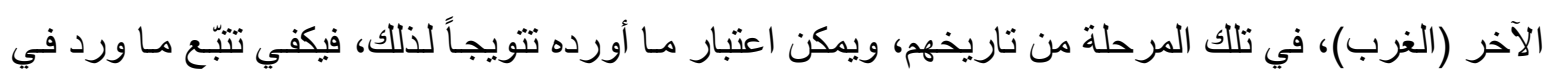

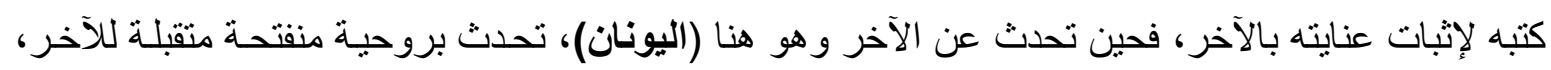

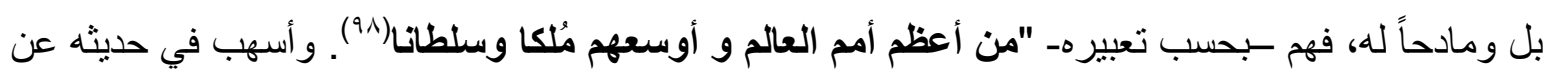

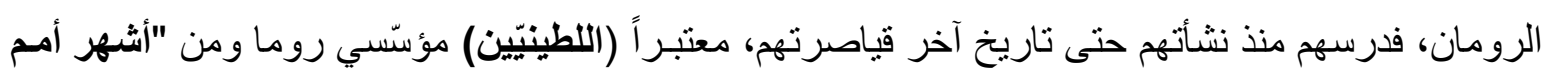

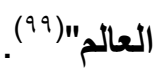

وبلغت رغبته في در اسـة الآخر و التعرف عليه، ان تنـاول جوانب متعددة من حياته، بمـا في ذلك

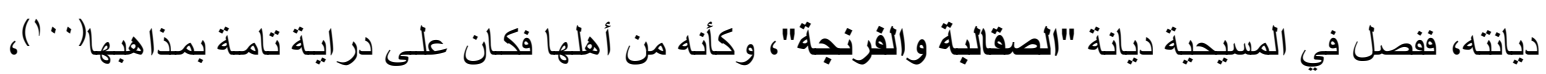

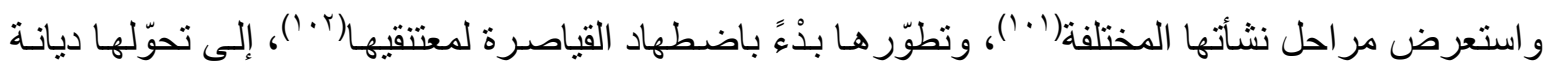

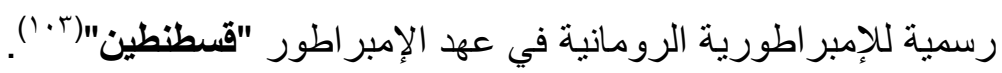

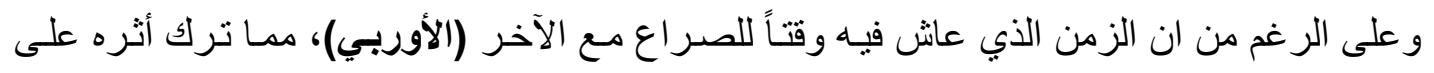

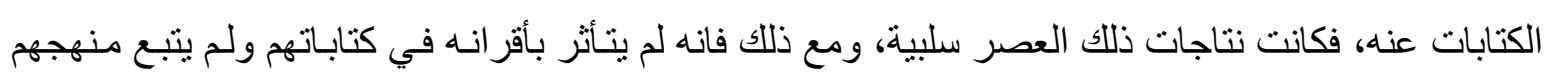
أو رؤيتهم للأوربيين، بل خط لنفسه رؤية خاصة منفتحة، فكتب عنهم بحيادية، بل لمح من بعيد بايجابية عالية

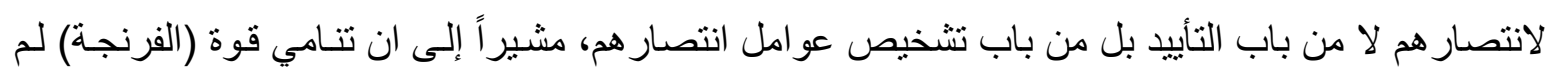

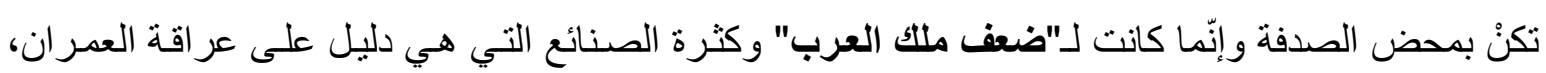
و هو ما أنشار اليه صراحة بقوله: "وأمم النصرانية عُدوة البحر الرومي أقوم النساس عليها (الصنائع) لأنهم

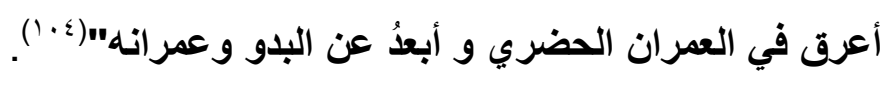

كما خلُص إلى أن الأمم التي لها تقليد قديم في الحضـارة، ومنها الأمم الأوروبيـة النصـر انية، تكون أكثر قابلية للعمران، لهذا نلحظ خلو قاموسـه الوصفيّ للآخر من عبـار ات الثتنيمة واللعنة، ولغة الحطّ التي

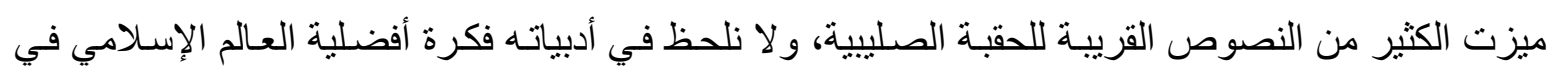
موازنته مع أوروبا المسيحية، وفي المنحى ذاته تباينت صورة الآخر الأوروبي لديـه عمّا كان عند غيره من المؤرخين الذين تأثروا في نظرتهم للغرب الأوربي بمخلفات الحروب الصليبية.

لقد تبلورت نظرته الحياديـة هذه للغرب بأثر رؤيته للتناريخ التي تمثلت بقوله: أنه "نظر وتحقيق

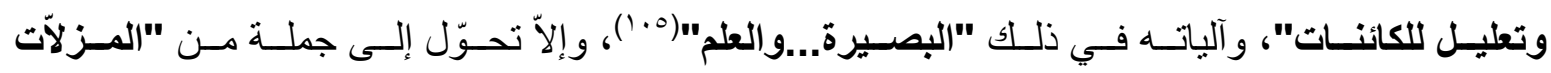

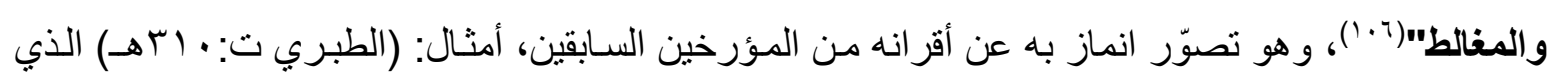

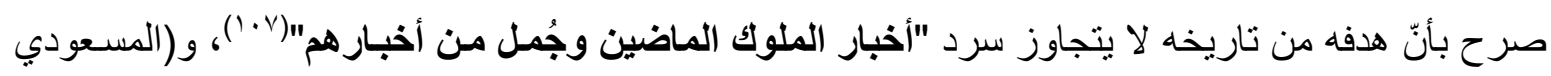

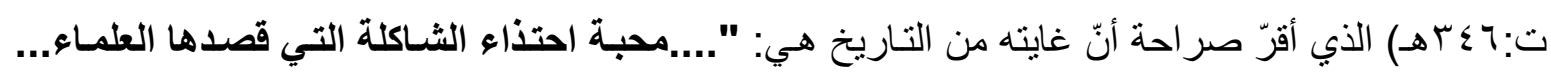

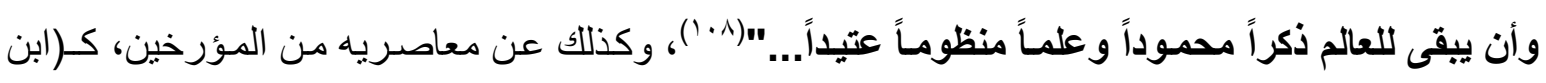

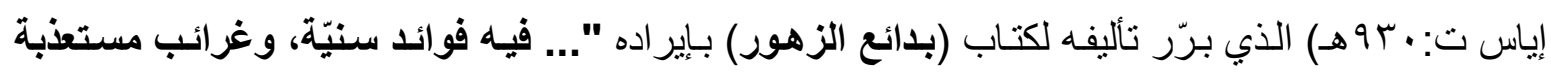

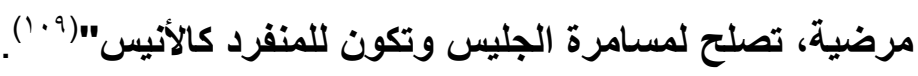




\section{الفاتمة- (الاستنتاجات والتوصيات):}

ممـا لاشك فيه ان البحث أثبت بالدليل ان الاستغراب لم يكن يومـا بـاب من ابو اب الترف الفكري

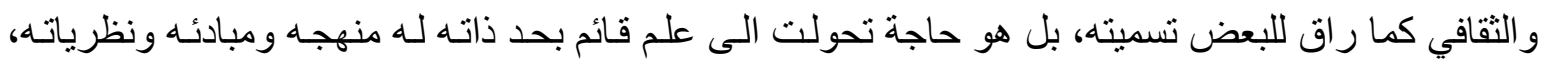
وتلكك الحاجة بدروها لم تتأتى من فراغ او في زمن متأخر، بـل هي حجـة توادت مـع و لادة الدولـة العربيـة الاسـلامية على الاقل على قدر تعلق الامر بالتـاريخ الاسـلامي، فمنذ اليوم الاول لنشـوء تلكـ الدولـة برزت الحاجـة فيهـا لدر اسـة نظير اتهـا الاقدم منهـا التـي كانت قائمـة ومزدهـرة يـوم ذاك كدول الروم و البيزنطيين و غير هم، اذا ان التعرف على طبيعة تللك الامم ومقوماتها وطبيعـة مجتمعاتها يسمح للدولة العربية الاسـلامية

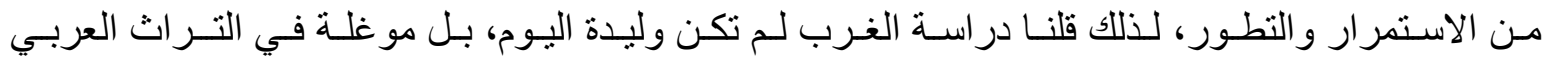
والإسلامي،

ومع ان تلك الدر اسة ظهرت جلية كفكرة ومفهوم في الكثير من كتابات المؤرخين العرب و المسلمين غير انها لم تأت وفق سياق واسلوب ناضج تاريخياً بحيث يمكن للقارئ البسيط وغير المختص ان يميز هـا عن غير ها بسهولة، بل جاءت وفق سياقات المنهجيـة التاريخية العامـة التي كانت متبعـة من قبل اغلب مؤرخينا العرب و المسلمين ما جلع تميز ها وفهمه ابعادها حكراً على الباحث المتمرس المختص.

تقودنـا تلك الافكـار الى استتناج مهمـة للغايـة هو ان الاستغر اب الذي ظهرت ملامحسه في كتابـات المؤرخين العرب و المسلمين لم يكن رد فعل آني على حركة استشـر اقية كمـا اعتقد البعض خطأ، انمـا نشطت وتبلورة جذوره ضمن سعي الكثير من المؤرخين المسلمين للاطلاع على حضسارة الغرب وتاريخهـ واستكمال الصورة المعرفية عن الغرب سواء كان في المجال الجغرافي او الاجتمـاعي او السياسي او الديني او غيرهـا من الجو انب، و التي انقسمت من حيث رؤية الباحثين لها الى قسمين كلاً بحسب موقفه من الغرب، مثل الأول رؤية سلبية جاءت متأثرة بتداعيات الغزو الصليبي للعـالم الاسـلامي، لهذا اكتنف البعض من الكتابـات صبغة انتقامية أكثر منها دراسـة تاريخيـة علميـة، فيمـا مثنل القسم الاخر من المؤرخين المسلمين نوعاً من الحياديـة المسندة للبحث و المعرفة وحب الاطلاع على الغرب وتجاوزوا النظرة السلبية في ذلك. ومهمـا اختلفت النظرة سلباً او ايجابـاً يبقى التو اصـل الحضـاري هو السمة المميزة في دفع المؤرخين العرب و المسلمين للاهتمـام بدر اسة الغرب ومتابعة أحواله.

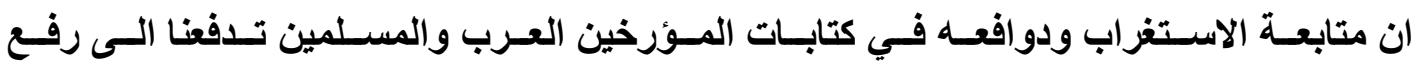

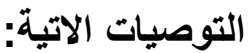

ا ـ أعادة قر اءة ما كتبه او نقله المؤرخون الاوائل عن الغرب وفقا للمبادئ العامـة لعلم الاستغراب، لفرز مـا نقل او كتب ودر استه ضمن المفاهيم الحديث لمعنى الاستغر اب.

r- الدعوة الى ترجمة كل ما كتب في الغرب عن معنى الاستغراب كما حدث مـع الاستشر اق ليتمكن الباحث من معرفة الكيفية التي ينظر بها الغربيون لمنهج المسلمين في دراسـة علم الاستغراب لخلق حلقة معرفية

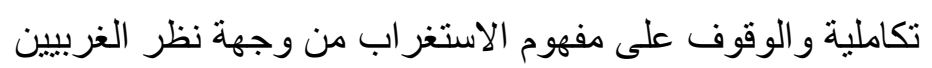


ك- تقديم الدر اسات التي تؤدي إلى تحسين وتوضيح ضـرورة دراسـة الآخر بمـا يقود إلى خلق الرغبـة للدى

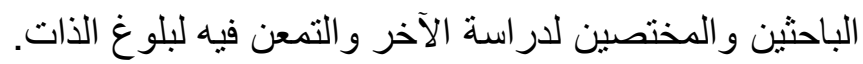
ع ـ الثروع بإنشاء مر اكز مختصة بدر اسة الاخر لتعميق مفهوم الاستغراب، لا على أسـاس ضد نوعي تجـاه الاستشراق، بل على أساس اعتبار احدهما مكملاً للآخر. هـ عرض التـراث العربي و الإسلامي الذي تنتاول الآخر جزء أو كلا إلى العلن بمـا يؤدي للقضـاء على فكرة حداثة در اسة الأخر وتجريمها. 7- إدخال تدريس علم الاستغراب في المناهج الدراسية لاسيما في المراحل الأولى من التعليم، لخلق ذهنية منفتحة تجاه الأخر وتقبل التو اصل معه مستقبلاً. V- رسم وتحديث الأطر العلمية والتاريخية التي يمكن من خلالها دراسـة الآخر دون الانسياق وراءه كحالة من التبيعة بمختلف أنو اعها و إثكالها. ^- عدم فهم ما قدمه التراث العرب و الإسلامي عن الأخر بصورته السلبية دون قياسه بزمان ومكان كتابته. 9- نوصـي بإعداد در اسـة شـاملة لكل الاتجاهـات العلميـة والاجتماعيـة و الاقتصـادية، وأن يـدرس وضـوع

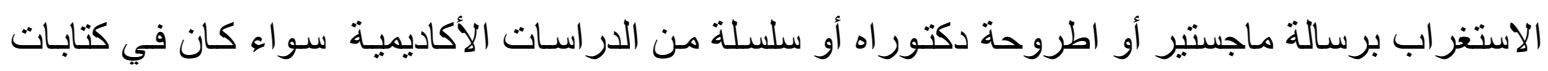
المؤرخين المسلمين أو عند الفقهاء المسلمين وغير ذلك من الثرائح الاجتماعية.

\section{هواهش البمث}

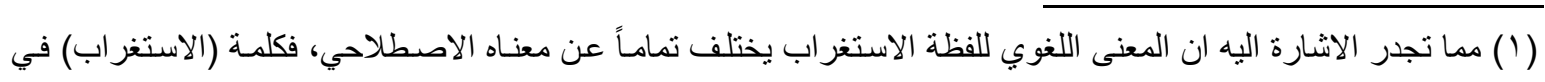

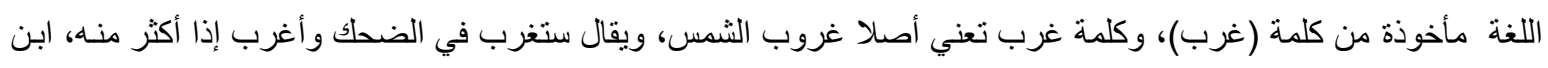

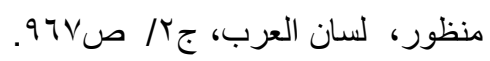

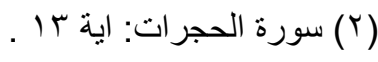

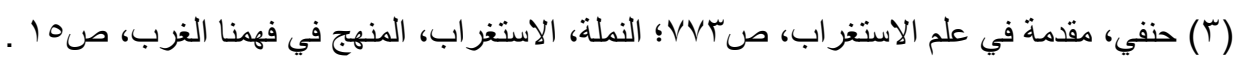

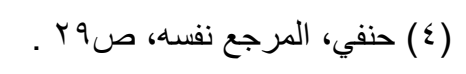

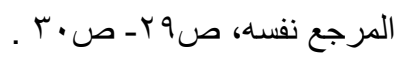

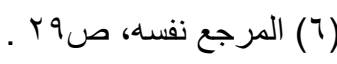

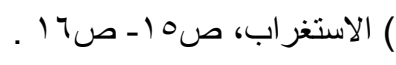

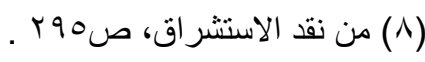

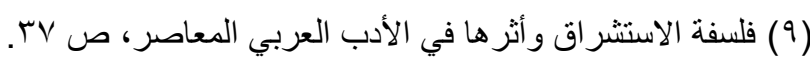
( (1) المقصود بـ(التغريب) عملية الاقبال على الغرب نقبل من خلالها مؤسسات الغرب ولاب وعلاقاته وقيمه.

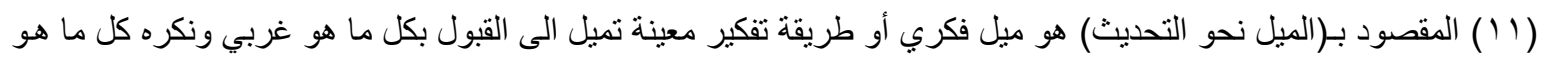

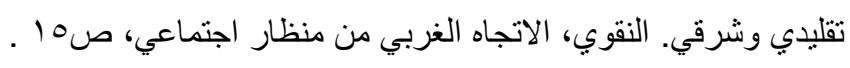

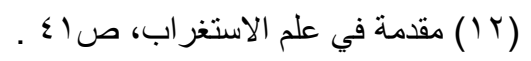

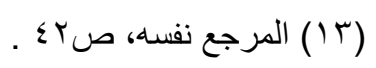

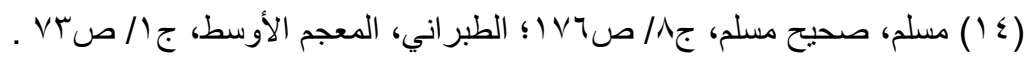




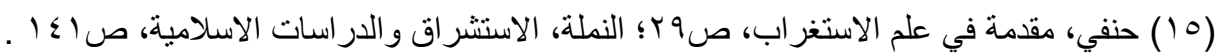

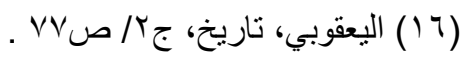

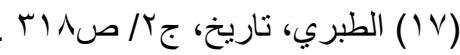

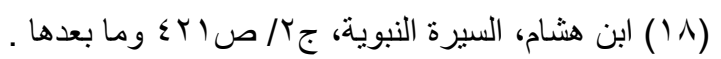

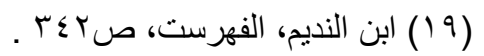

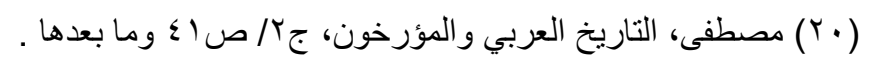

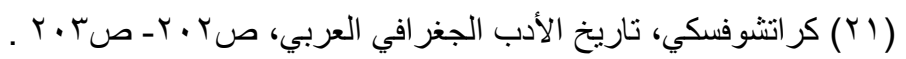

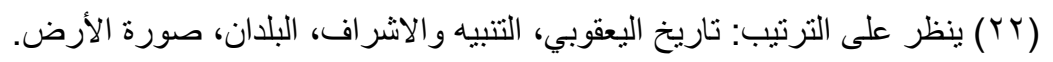

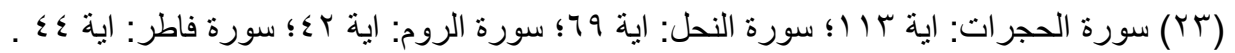

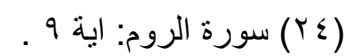

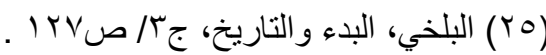
( آل

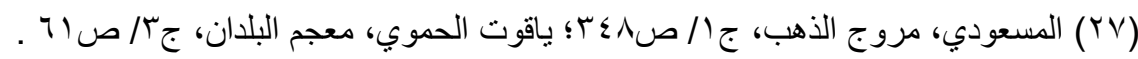

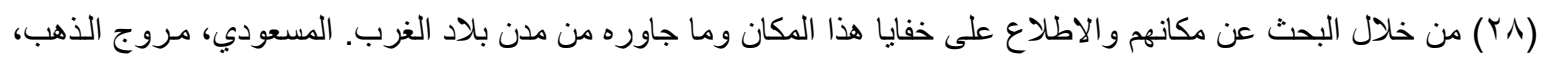

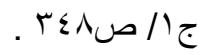

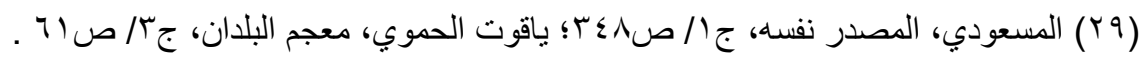

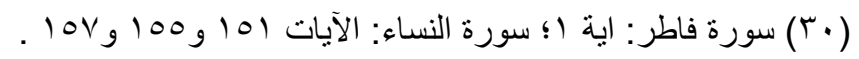

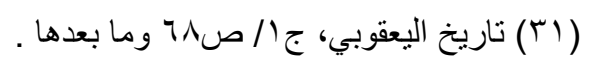
(r)

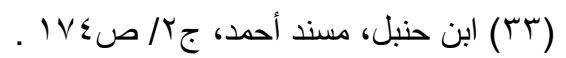

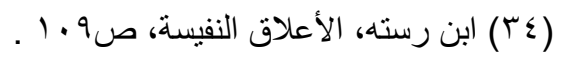

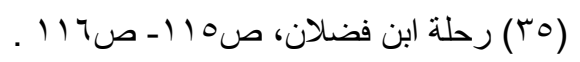

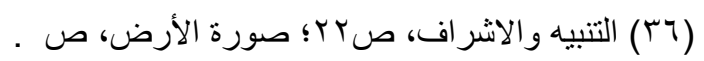

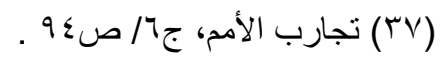

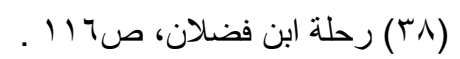

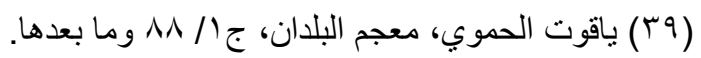

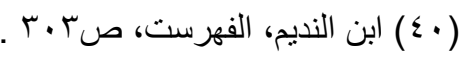

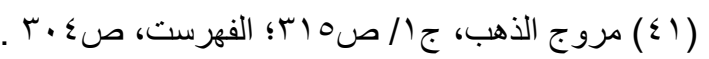

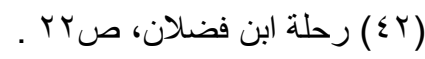

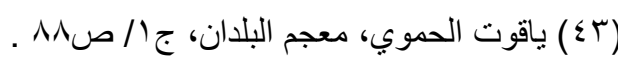

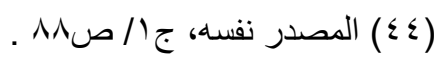

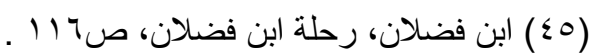

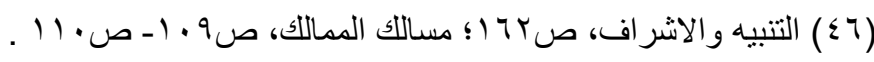

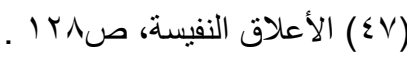

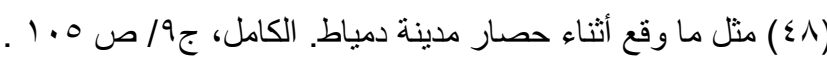

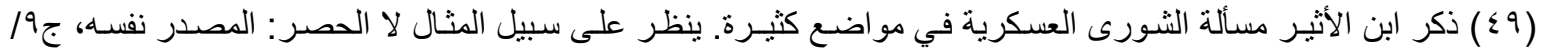




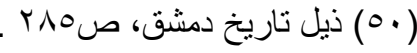

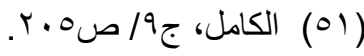

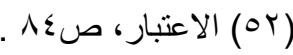

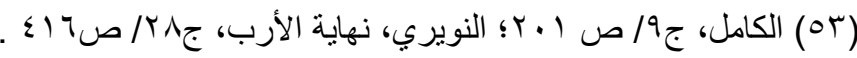

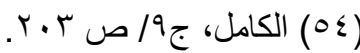

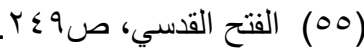

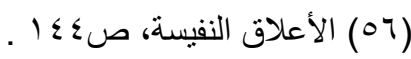

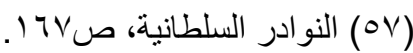

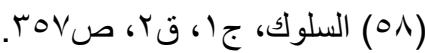

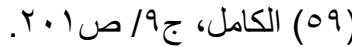

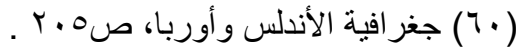

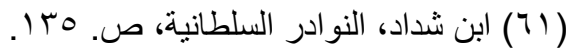

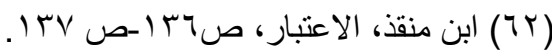

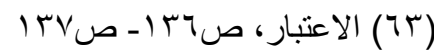

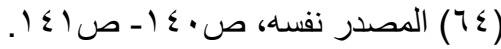

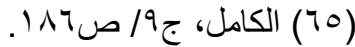

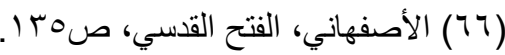

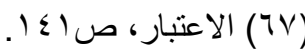

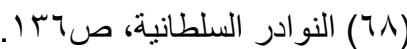

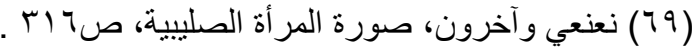

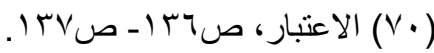

(Y)

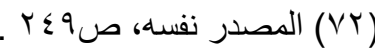

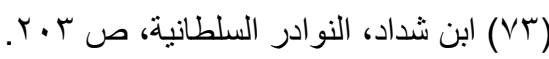

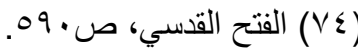

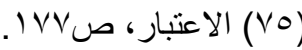

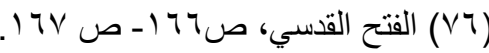

ابن الأثير، ج· (IV)

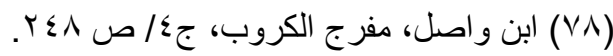

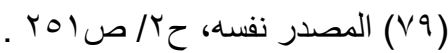

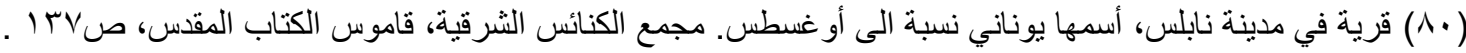

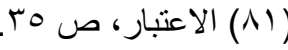

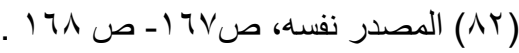

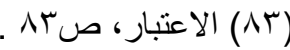

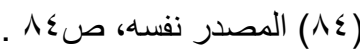

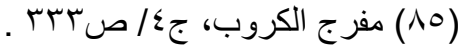

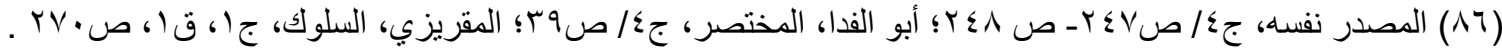




$$
\begin{aligned}
& \text { (AV) }
\end{aligned}
$$

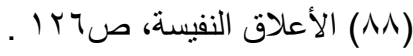

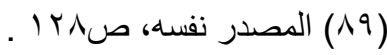

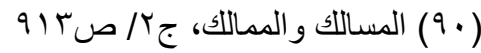

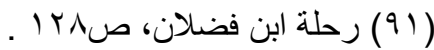

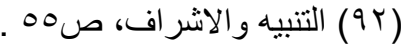

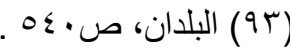

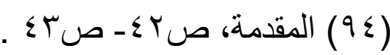

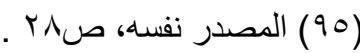

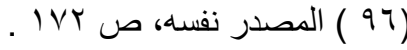

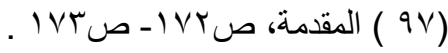

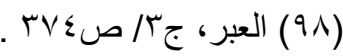

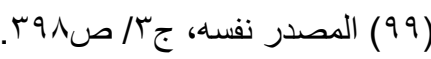

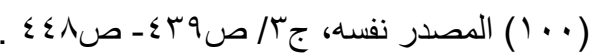

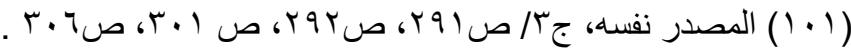

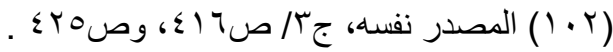

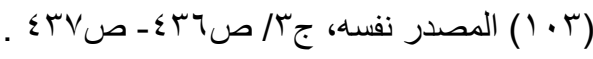

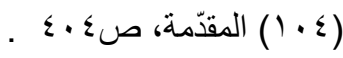

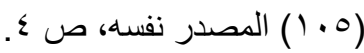

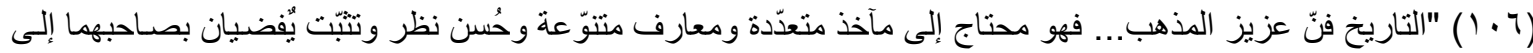

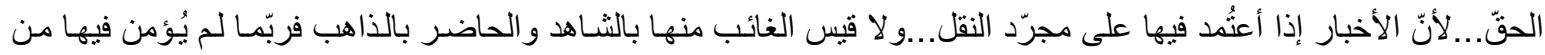

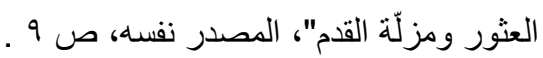

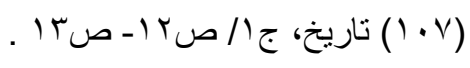

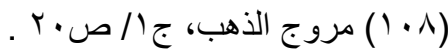

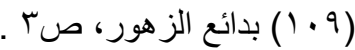

\section{هصادر البحث وهراجعه}

خير ما نفتتح به القران الكريم * ابن الأثير، عز الدين أبو الحسن علي بن محمد الجزري (ت.بآهـ):

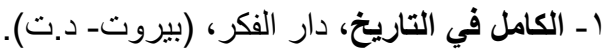

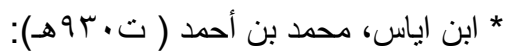

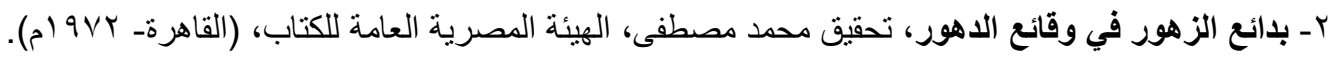

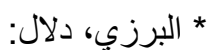
r- الاخر، المفارقة الضرورية، بحث منشور ضمن كتاب الاخر العربي ناظراً ومنظوراً اليه، (د.م- (991).

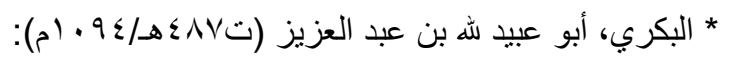
ع - جغرافية الأندلس وأوربا، تحقيق عبد الرحمن الحجي، دار الارشاد، (بيروتـ 941 (اتم).

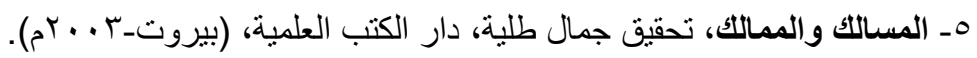
* البلخي، أبو زيد أحمد بن سهل (ت ع مهـ): 
ד- البدء و التاريخ، (باريس- (1999 (م)).

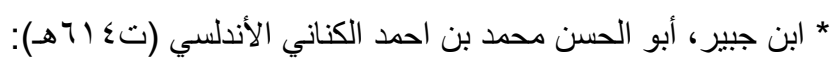
V- رحلة ابن جبير، تحقيق وتقديم: د. محمد مصطفى زيادة، دار الكتاب اللبناني، دار الكتاب المصري، لهين (بيروت- القاهرة- د.ت).

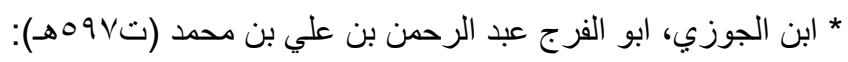

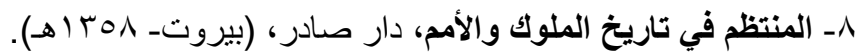

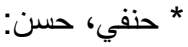
9ـ مقدمة في علم الاستغراب، "التراث و التجديد، موقفنا من التراث الغربي"، الدار الفنية، (القاهرة- (99 (م).

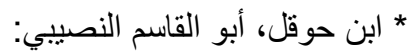

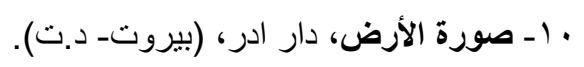

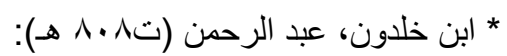
1اـ العبر وديوان المبتدأ والخبر في أيام العرب والعجم والبربر، ومن عاصرهم من ذوي العلطان الأكبر، الثركة العالميـة

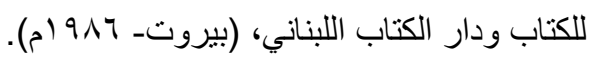

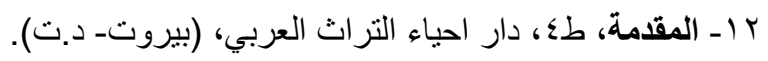

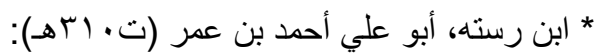

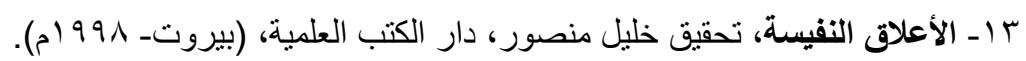

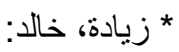

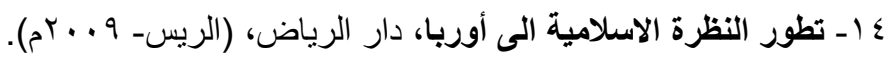

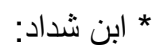

1 1 ـ النوادر السلطانية والمحاسن اليوسفية، تحقيق: جمال الدين الثيال، (د.م- ع 99 (م). * الثيخ، أحمد:

ا 17 ـ من نقد الاستثراق الى نقد الاستغراب، (القاهرة- 999 مام).

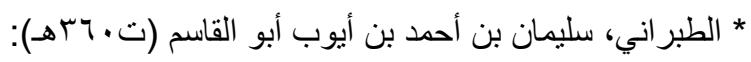

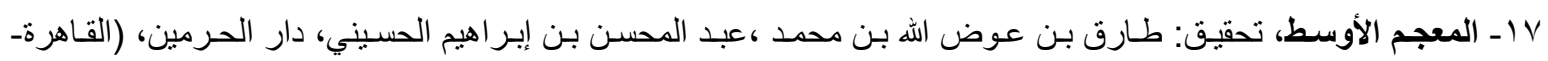
(ه) $\leqslant 10$

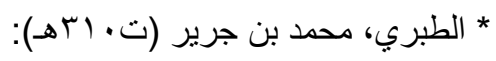

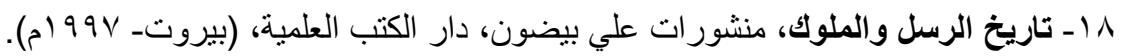

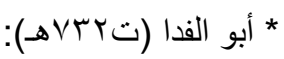
9 ا ــ المختصر في تاريخ البشر ، دار المعرفة اللطباعة والنشر، (بيروت- د.ت).

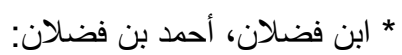

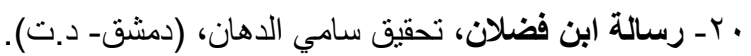

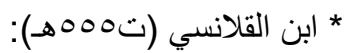

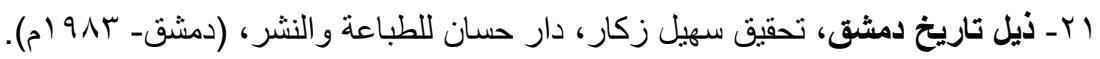

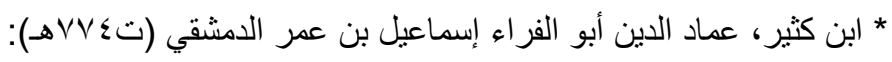

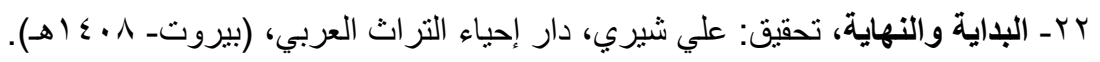

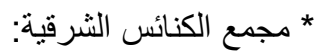
بr- قاموس الكتاب المقدس، طَ، (بيروت- (919)م).

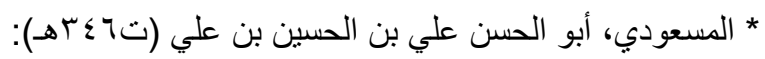


§ ؟ - التتبيه والاشر اف، دار صعب، (بيروت- د.ت).

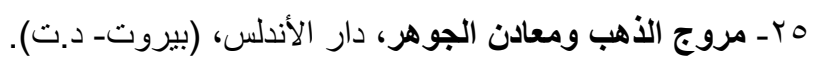

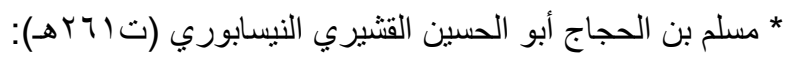

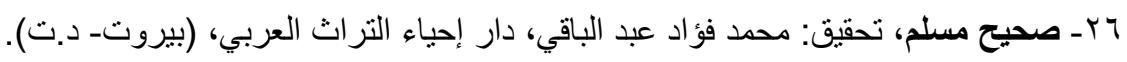

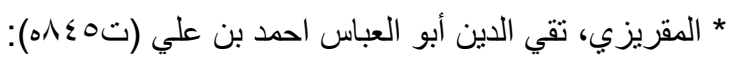

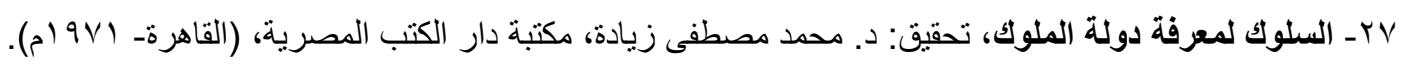

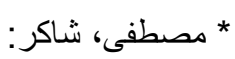

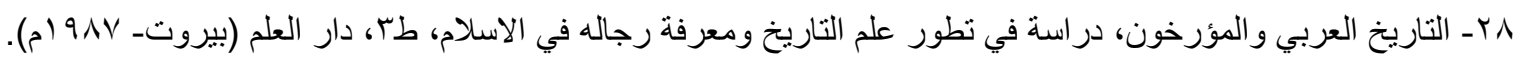

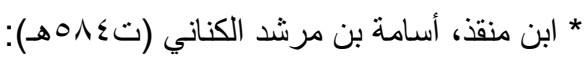

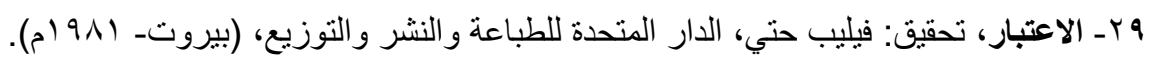
* ن نعنعي، عبد المجيد و اخرون:

• بـ صورة المرأة الصليبية في ظل الاحتلال الافرنجي، بحث نشر ضمن كتاب المناطق اللبنانية في ظل الاحتلال الفرنجي، منشور ات فيلون، (لبنان- 99 (1)م). * النقوي، علي محمد:

(الــ الاتجاه الغربي من منظار اجتماعي، منظمة الإعلام الإسلامي، (د.م- 9199 ( ).

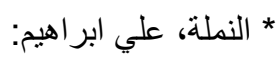

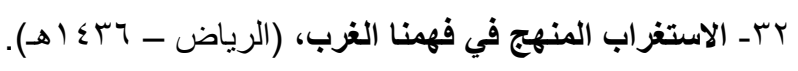

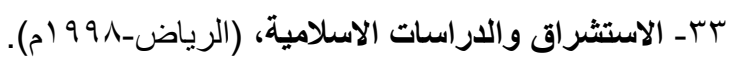

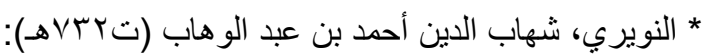

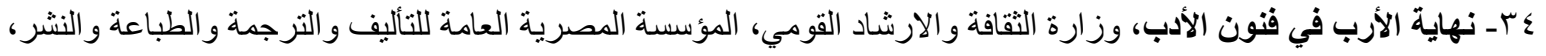

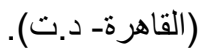

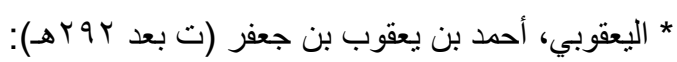
هــ تاريخ اليعقوبي، دار صادر، (بيروت- د.ت). 